\title{
Using Artificial-Reef Knowledge to Enhance the Ecological Function of Offshore Wind Turbine Foundations: Implications for Fish Abundance and Diversity
}

\author{
Maria Glarou ${ }^{1,2, *} \oplus$, Martina Zrust ${ }^{1}$ and Jon C. Svendsen ${ }^{1}$ \\ 1 DTU Aqua, Technical University of Denmark (DTU), Kemitorvet, Building 202, 2800 Kongens Lyngby, \\ Denmark; martinazrust@icloud.com (M.Z.); jos@aqua.dtu.dk (J.C.S.) \\ 2 Department of Ecology, Environment and Plant Sciences, Stockholm University, Svante Arrhenius \\ väg $20 \mathrm{~A}$ (or F), 11418 Stockholm, Sweden \\ * Correspondence: maria_glarou@outlook.com; Tel.: +45-50174014
}

Received: 13 April 2020; Accepted: 5 May 2020; Published: 8 May 2020

\begin{abstract}
As the development of large-scale offshore wind farms (OWFs) amplifies due to technological progress and a growing demand for renewable energy, associated footprints on the seabed are becoming increasingly common within soft-bottom environments. A large part of the footprint is the scour protection, often consisting of rocks that are positioned on the seabed to prevent erosion. As such, scour protection may resemble a marine rocky reef and could have important ecosystem functions. While acknowledging that OWFs disrupt the marine environment, the aim of this systematic review was to examine the effects of scour protection on fish assemblages, relate them to the effects of designated artificial reefs (ARs) and, ultimately, reveal how future scour protection may be tailored to support abundance and diversity of marine species. The results revealed frequent increases in abundances of species associated with hard substrata after the establishment of artificial structures (i.e., both OWFs and ARs) in the marine environment. Literature indicated that scour protection meets the requirements to function as an AR, often providing shelter, nursery, reproduction, and/or feeding opportunities. Using knowledge from AR models, this review suggests methodology for ecological improvements of future scour protections, aiming towards a more successful integration into the marine environment.
\end{abstract}

Keywords: scour protection; offshore wind farm; renewable energy; artificial reef; ecosystem restoration; ecological engineering

\section{Introduction}

Humans rely upon and utilize the marine environment for a variety of ecosystem services and valuable resources, leaving no parts of the oceans unaffected [1,2]. The majority of people live in the coastal zones, where anthropogenic activities have been progressively altering the seascape [3-5], resulting in direct and indirect negative impacts on marine biota [6]. The introduction and proliferation of artificial (i.e., engineered) structures to marine ecosystems, driven by commercial and residential demands, causes a phenomenon known as "ocean sprawl" [7]. "Ocean sprawl" refers to a marine environment that is increasingly becoming dominated by artificial structures, including artificial reefs, breakwaters, seawalls, piers, oil platforms, and marine renewable energy installations [7], often causing various effects on the surrounding ecosystems [8].

An artificial reef (hereafter abbreviated as "AR") may be defined as a structure of "natural or human origin deployed purposefully on the seafloor to influence physical, biological, or socio-economic 
processes related to living marine resources" [9]. A designated AR can be employed for a variety of purposes, with a primary aim being biological conservation and fisheries enhancement, extending also to ecosystem restoration, as well as socioeconomic development $[10,11]$. Specific AR purposes may include aquaculture/sea-ranching, biomass increase, biodiversity enrichment, fisheries production, ecosystem management, prevention of coastal erosion, recreational activities (e.g., scuba diving, ecotourism, fishing), and research $[10,12,13]$. These engineered structures are typically constructed to resemble natural reefs as much as possible, with the ultimate goal to produce similar effects. There are also other structures acting as ARs that (a) have entered the marine environment accidentally (e.g., shipwrecks, lost containers), (b) have been repurposed (e.g., sunken ships for recreational activities) or (c) serve other functions (e.g., offshore oil and gas platforms) [14-17].

Another example of man-made infrastructure are offshore wind farms (hereafter abbreviated as "OWFs"). OWFs are increasingly established in marine areas with the purpose to meet the rising global demand for renewable energy $[18,19]$. Apart from the obvious benefits provided by renewable energy, OWFs may have several ecological effects on the marine environment. Ecological disruptions caused by OWF include avian collisions [20,21], underwater noise [22-24] and electromagnetic fields [18,25,26], as well as loss of soft-bottom habitat with the introduction of hard substrata [27]. Other changes caused by OWFs include increased abundance and biodiversity of hard-bottom species due to reef effects and creation of no-take zones within the OWF, with possible spill-over effects to neighbouring areas [28-30].

OWFs typically consist of an array of individual wind turbines placed on soft-bottom habitats. Since offshore wind turbines are located on soft sediment, scouring inevitably occurs around their foundations. Scour is created when a steady current (e.g., tide, wave activity) encounters a vertical structure on the seabed, causing local increases in flow speeds and turbulence levels and ultimately leading to the creation of a scour pit around the structure [31]. Scouring may compromise the stability and dynamic behaviour of wind turbine foundations [32]. The magnitude of scouring is affected by the current speeds, the water depth and sediment types [31].

Scour protection is a measure used to prevent the erosion of seabed sediment around individual foundations of offshore wind turbines [33]. Typically, scour protection consists of a filter layer made of gravel, shielded by a rock armour layer [34] (Figure 1). The material is placed around the foundation of the turbine (e.g., around the monopile) with a radius typically reaching up to $20 \mathrm{~m}[34,35]$. The size and design of the scour protection is determined by a range of environmental factors (i.e., wave and current activity, water depth, sediment characteristics), as well as structural factors (i.e., monopile diameter and design) [36,37] (Figure 1). Generally, the size of the scour protection area reflects the area of the scour pit that would arise due to the environmental factors (e.g., current speed), if the foundation was left unprotected [31], which is usually four to five times the monopile diameter [38].

It is increasingly recognized that the changes introduced during the Anthropocene, including ocean sprawl and coastal hardening, have transformative effects on natural ecosystems $[7,39,40]$. Hence, the establishment of a mutually beneficial relationship between biota and man-made infrastructure is crucial. The concept of "renewal ecology", introduced by Bowman et al. [41], falls directly under this scope. Renewal ecology is defined as "a solutions-focused discipline aimed at creating and managing ecosystems designed to maximize both biodiversity and human well-being in the face of rapid environmental change" [41]. Although renewal ecology remains to be embraced widely, especially in the marine environment, the concept is progressively gaining support. Importantly, renewal ecology resembles IUCN's principles of "Nature-based solutions", which was recently embraced by the commission of the European Union [42]. For example, coastal defence structures are increasingly constructed not only to meet engineering requirements, but also to enhance biodiversity and provide ecosystem services [11]. Moreover, in terms of OWFs, the Netherlands recently introduced new permit obligations, requiring engineers to "make demonstrable efforts to design and build the wind farm in such a way that it actively enhances the sea's ecosystem, helping to foster conservation efforts and goals relating to sustainable use of species and habitats" [43]. These new obligations recognize the 
increasing presence of anthropogenic infrastructures in the marine environment and therefore seek to design OWFs in a fashion where positive effects exceed negative effects for the marine biota.

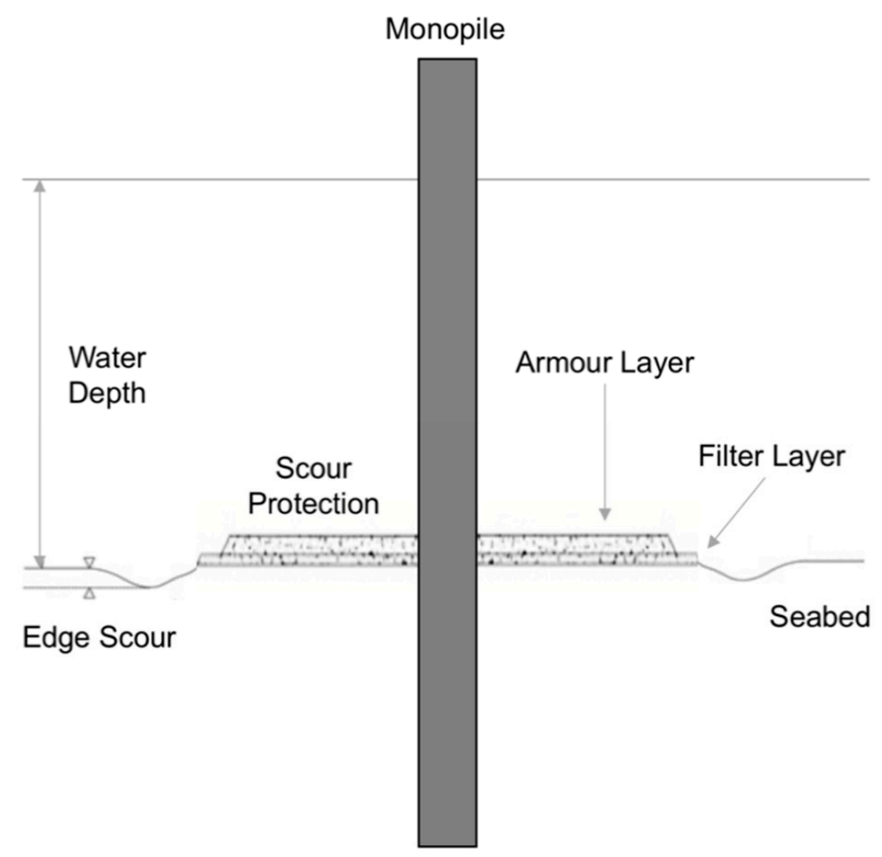

Figure 1. Illustration of a common scour protection design, modified from Whitehouse et al. [38]: Scour protection around an offshore wind turbine, laid on the seafloor. The vertical bar represents the monopile that holds the windmill rotor and turbine. The scour protection includes a preinstalled filter layer of small-sized rocks (e.g., $5 \mathrm{~cm}$ in diameter) covered by an armour layer of larger rocks (e.g., $40 \mathrm{~cm}$ in diameter). The filter layer prevents erosion of sand through the upper layer of larger rocks. The filter layer is usually about $0.5 \mathrm{~m}$ high, whereas the armour layer is about $1 \mathrm{~m}$ high. Edge scour (e.g., $0.5 \mathrm{~m}$ deep) may develop in the periphery of the scour protection. Further details on scour protection designs are provided by Whitehouse et al. [38]. In the present review, the foundation is defined as the monopile and the surrounding scour protection, as illustrated in the figure.

\section{Objectives}

The concept of eco-engineering man-made infrastructure is increasingly discussed in the existing literature [44-46], however, to date, no review has investigated how scour protection in OWFs may be tailored to create productive habitats for various fish species. The present review aims to fill this void by synthesizing current evidence on changes in the abundance and diversity of fish and commercially exploited species in response to the establishment of OWFs in temperate seas and relating this knowledge to existing AR research. The overarching goal is to extract current knowledge of AR designs and use it to suggest scour protection refinements aimed at supporting fish abundance and diversity. Ultimately, improved fish production attributed to scour protection may support commercially exploited fish stocks and contribute to sustainable fisheries. The review concludes by identifying knowledge gaps and suggesting future research directions. Only ARs designed with a purpose (e.g., increasing species abundance and diversity) and designed similarly to scour protection (e.g., gravel, rocks, stones, granite, boulders etc.) were examined in this review, while accidental ARs (e.g., shipwrecks) [12] were disregarded. This allowed for comparisons between ARs and scour protections with the purpose of revealing various AR design refinements that could be transferable to future scour protection construction. Additionally, studies occurring in non-temperate regions were excluded, because the majority of OWFs occur in temperate marine waters. 


\section{Materials and Methods}

The present study was conducted following the systematic literature review protocol developed by Pullin and Stewart [47]. The guidelines have been used by numerous systematic reviews related to offshore energy, including reviews concerning the potential of OWFs to act as marine protected areas [30] and the impacts of energy systems on marine ecosystem services [48].

\subsection{Search Terms}

A wide range of search terms were selected to incorporate all the components of the study objectives. The specific search terms were formulated to gather all relevant literature from the databases. Similar to previous systematic reviews [49], negative terms were included to increase the efficacy of the string and to remove impertinent search results. Applied search terms are listed in Table 1 , where terms with an asterisk $(*)$ represent a search engine wild-card [49]. These search terms were applied to two different databases: "Web of Science" and "Scopus".

Table 1. Selected search terms used in "Web of Science" and "Scopus".

\begin{tabular}{|c|c|}
\hline TechnicalTerms & $\begin{array}{l}\text { artificial reef }{ }^{*} \text {, reef effect } * \text {, fish attraction device }{ }^{*} \text {, artificial structure } * \text {, scour } \\
* \text {, scour }{ }^{*} \text { protection } * \text {, scour control } * \text {, wind power foundation } * \text {, offshore } \\
\text { wind, wind farm foundation } * \text {, turbine foundation } * \text {, offshore energy, offshore } \\
\text { wind energy structure } * \text {, artificial offshore construction } * \text {, offshore wind farm } * \text {, } \\
\text { wind turbine } * \text {, rock armour }{ }^{*}\end{array}$ \\
\hline Ecosystem-Related Terms & 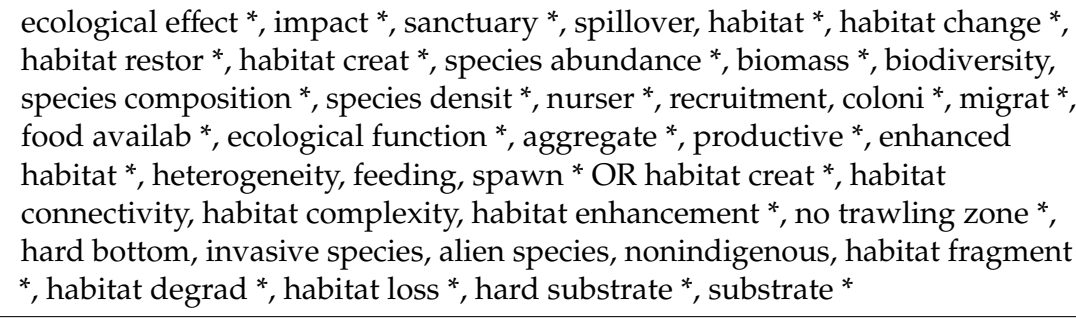 \\
\hline Target Species Group Term & fish * \\
\hline Negative Terms & tropical, subtropical, Caribbean, Indian Ocean \\
\hline
\end{tabular}

\subsection{Screening Process}

The papers resulting from the searches were assessed for relevance at three sequential levels: title, abstract, and full text [47]. Papers included in the analyses fulfilled the inclusion criteria (Table 2).

Table 2. Inclusion and exclusion criteria for the systematic review.

\begin{tabular}{ccc}
\hline Criteria & Include & Exclude \\
\hline Peer-reviewing & Peer-reviewed studies & Reviews \& everything else \\
Text Language & English & Everything else \\
Years & All years (1900-2018) & - \\
Location & Temperate seas & Everything else \\
Intervention & OWFs and designated ARs & Accidental ARs, such as shipwrecks \\
Subject & Fish and fisheries & Everything else \\
\hline
\end{tabular}

\subsection{Data Extraction}

Study characteristics and the findings of the resulting papers were recorded (Table 2). Specifically, documented details included: (a) the type of structure (e.g., AR, OWF and the associated scour protection), (b) the spatial scale of the study (e.g., area of AR or scour protection), (c) the temporal scale 
of the study (e.g., time elapsed after the deployment of structure), (d) the physical characteristics of the structure (e.g., material, shape), and (e) the examined variables (e.g., fish abundance and diversity).

\subsection{Data Analysis}

A quantitative analysis was conducted based on the data extracted by parsing the literature over 1900-2018. Relevant literature was limited within a 37-year period (1982-2018), and for each year, the total number of AR and OWF papers was recorded. Similar to previous reviews [49], the accumulated number of papers for both subjects was plotted across time and general linear regression was applied to identify research trends. In addition, further analyses compared various parameters related to scour protection and ARs (e.g., material and water depth). Statistical analyses were carried out using the free software R Studio (R Core Team, 2019).

\section{Results}

\subsection{Selection Process}

The selection process resulted in 7,027 papers, with a total of 6,537 remaining after duplicate removal. Following the removal of irrelevant subjects, locations, and reviewing the material through title, abstract, or full-text analysis, a total of 115 peer-reviewed papers met the inclusion criteria (Table 2; Figure 2). Of those, 89 and 26 papers pertained to ARs and OWFs, respectively.

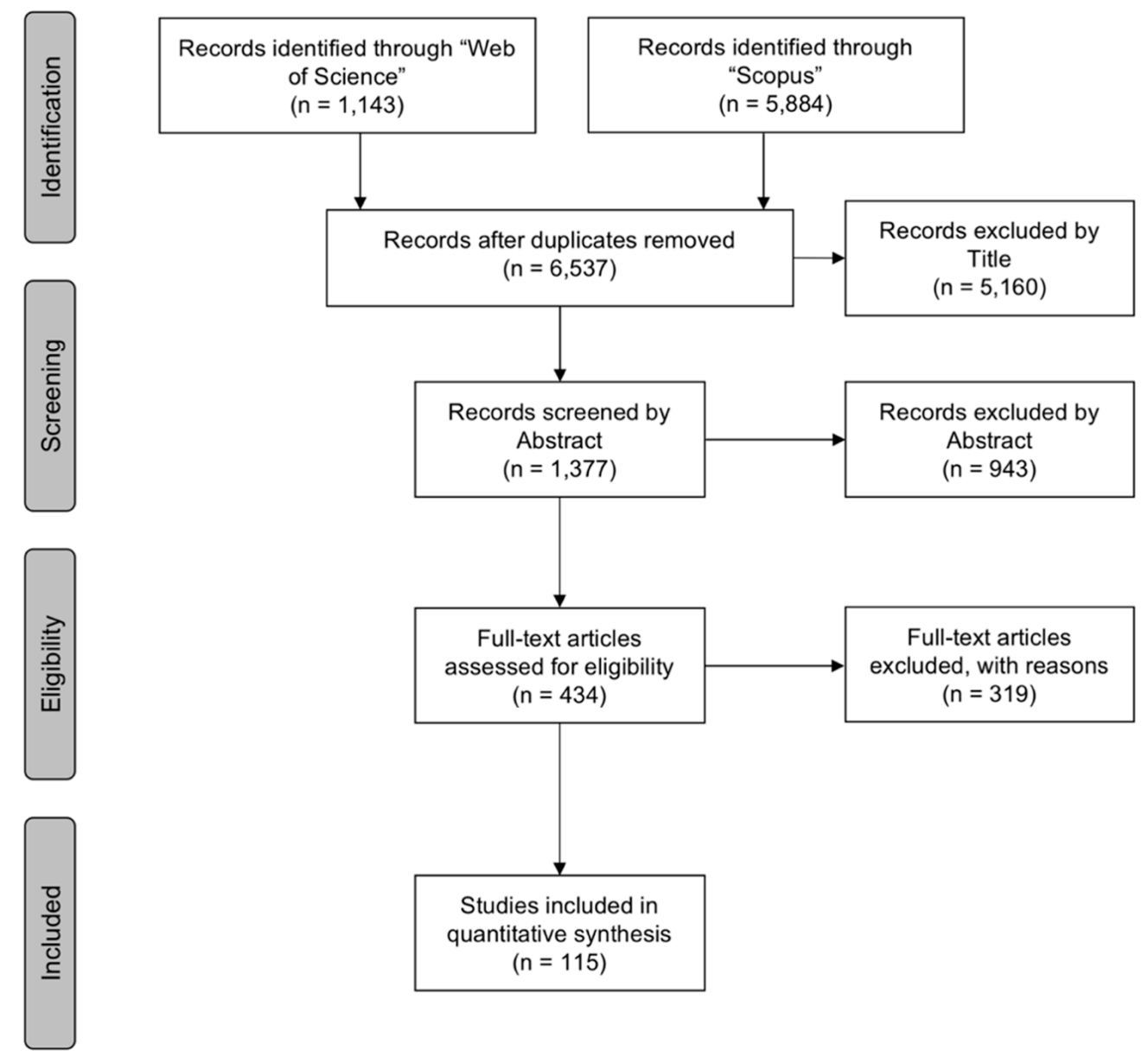

Figure 2. A "PRISMA" diagram showing the flow of information through the different phases of the review [50]. 


\subsection{Temporal Research Trends}

Published AR research started in the early 1980s, whereas OWF research started around the mid 2000s (Figure 3). Despite this time difference, both topics reveal increasing trends (ARs: $R^{2}=0.34$, $p<0.001$; OWFs: $R^{2}=0.39, p<0.001$ ). Earlier peer-reviewed literature could possibly be non-accessible due to historical limitations of certain search databases (e.g., Web of Science), creating potential bias in regard to the commencement of research on both topics.

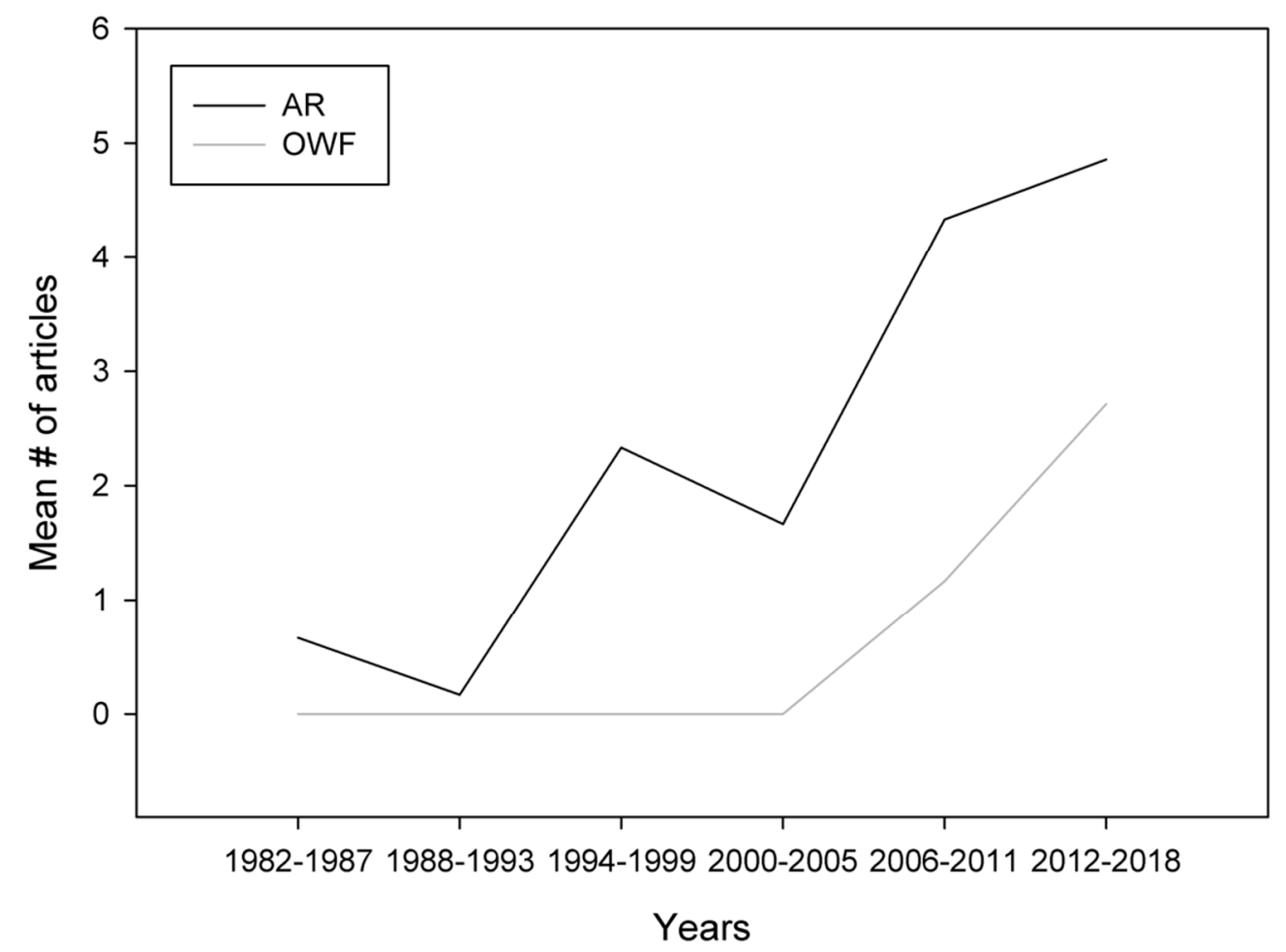

Figure 3. Trends of research output (articles per year) for artificial reef (AR) and offshore wind farm (OWF) studies through the years 1982-2018 (source: Web of Science, Scopus). For clarity, data are presented in six-year intervals, with the exception of the 2012-2018 period, which includes seven years. This unequal division was necessary to address the total period of 37 years that contained all articles fulfilling the inclusion criteria. Regardless of the duration of the time interval (six or seven years), data are presented as the mean number of articles per year from each time interval.

\subsection{Location of Available Studies}

Many AR studies originated from Southern Europe, Southwest USA and East Asia (Figure 4). In contrast, OWF studies mainly originated from northern Europe, particularly within the North Sea (including Belgium, Denmark, Germany, the Netherlands and the UK) (Figure 4). This indicates geographical differences between AR research and OWF research. Only Germany and the USA have covered both topics (Figure 4). 


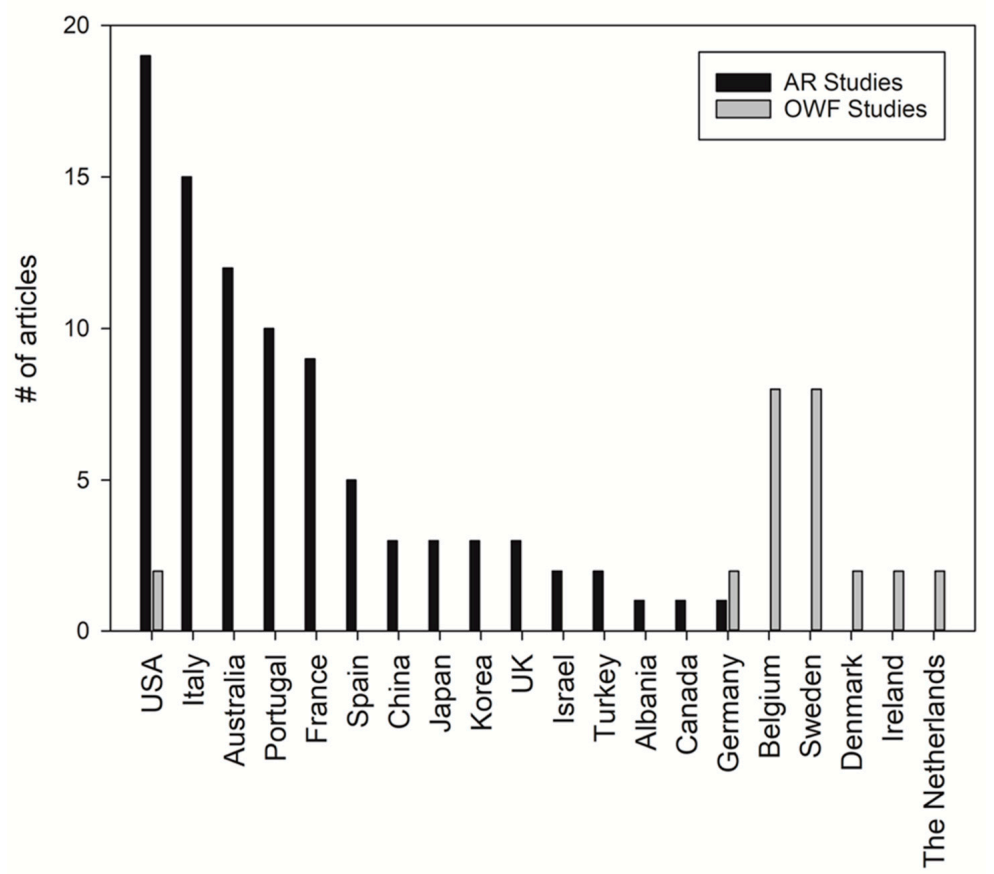

Figure 4. Number of artificial reef (AR) and offshore wind farm (OWF) studies per country throughout the years 1982-2018 (source: Web of Science, Scopus).

\subsection{Inconsistent Study Details}

The amount of study details varied between papers (Table 3). All studies reported the sampling method, whereas fewer studies included information about the spatial scale and the material used for the structure (Table 3).

Table 3. A list of 17 variables reported in the articles that met the inclusion criteria (Table 2), similar to Whitmarsh et al. [51]. The table provides examples of the variables that were reported in each article, as well as the percentage of articles that mentioned each specific variable. For example, regarding the spatial scale of an AR or OWF (variable 8 from the top), an example of $700 \mathrm{~m}^{2}$ is provided. This means that at least one of the reviewed articles examined an AR or OWF area covering $700 \mathrm{~m}^{2}$. The rest of the included examples follow the same logic and are not general findings.

\begin{tabular}{|c|c|c|c|}
\hline Variable & Examples & $\begin{array}{c}\% \text { of AR Studies Reported in } \\
\text { (\% Out of } 89)\end{array}$ & $\begin{array}{c}\% \text { of OWF Studies Reported in } \\
(\% \text { Out of } 26)\end{array}$ \\
\hline \multicolumn{4}{|l|}{ General } \\
\hline Type of Study & Scientific Paper, Report & 100 & 100 \\
\hline Year published & 2000, 2018 & 100 & 100 \\
\hline Location & Italy, North Sea, UK & 100 & 100 \\
\hline \multicolumn{4}{|l|}{ Study Design } \\
\hline Sampling method & Visual census, Fishing & 100 & 100 \\
\hline Study design & BACI $*$ Impact only & 92 & 96 \\
\hline Temporal Scale & 10 years after deployment & 79 & 69 \\
\hline Sampling Season & Summer, Winter & 82 & 92 \\
\hline \multicolumn{4}{|l|}{ Structure } \\
\hline Spatial Scale & $700 \mathrm{~m}^{2}$ & 44 & 54 \\
\hline Depth & $30 \mathrm{~m}$ & 76 & 61 \\
\hline Material & Concrete, rock & 84 & 61 \\
\hline Shape of material & Cube, boulder & 79 & 0 \\
\hline Volume of material & $1 \mathrm{~m}^{3}$ & 52 & 4 \\
\hline \multicolumn{4}{|l|}{ Effects on Fish } \\
\hline Overall impact &,$++/-,-$ & 94 & 88 \\
\hline Biomass/Abundance &,$++/-,-$ & 72 & 73 \\
\hline Diversity &,$++/-,-$ & 48 & 38 \\
\hline Shelter (Complexity) & Yes, No, Possibly & 34 & 85 \\
\hline Spawning/Settlement & Yes, No, Possibly & 22 & 31 \\
\hline
\end{tabular}

+ Increase; - Decrease; +/- No noticeable effect; ${ }^{*}$ Before-after-control-impact experimental design. 


\subsection{Overlapping Use of Materials for ARs and OWFs}

Variable materials have been used for ARs and OWFs (Figure 5). In some occasions, ARs were created using various types of rocks [52,53], but the majority of ARs were made using designed concrete units [12]. Other AR components included metal and scrap materials [54,55] (Figure 5). Some AR studies compared different materials, sizes and shapes used for the construction of ARs and included more eco-friendly materials [56,57]. In contrast, scour protection structures commonly consisted of various rock types (stones, pebbles etc.), with $61 \%$ of the literature reporting on at least one of these materials (Figure 5). For the rest of the OWF studies (39\%), the material used for scour protection was not described. Thus, evidence suggested that scour protection is mainly made of rocks.

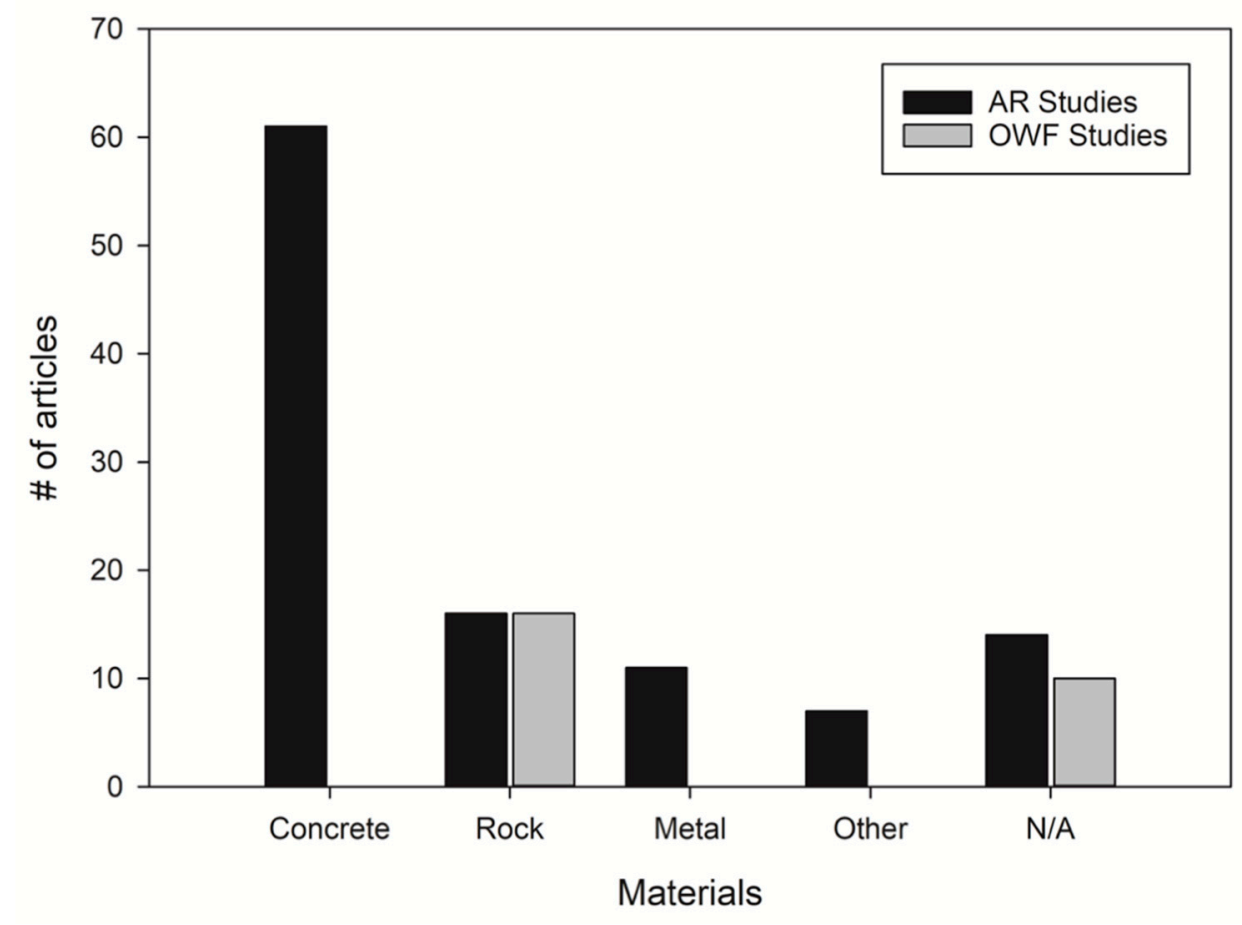

Figure 5. Materials used for artificial reefs (ARs) and scour protection associated with offshore wind farms (OWFs). Some papers are included in multiple categories, because they studied more than one material. "Other" includes scrap materials, wood, tires and PVC materials. "N/A" means that the material used was not specified in the articles.

\subsection{Overlapping Water Depths Used for ARs and OWFs}

Water depths of many AR and OWF studies are overlapping (Figure 6). The majority of AR and OWF studies concern structures that are located at water depths between 15 and $30 \mathrm{~m}$. Studies related to OWFs are, however, absent at water depths exceeding $30 \mathrm{~m}$. This is largely due to OWF foundation typology, as monopiles (Figure 1) are rarely constructed at water depths exceeding $30 \mathrm{~m}$ [58]. 


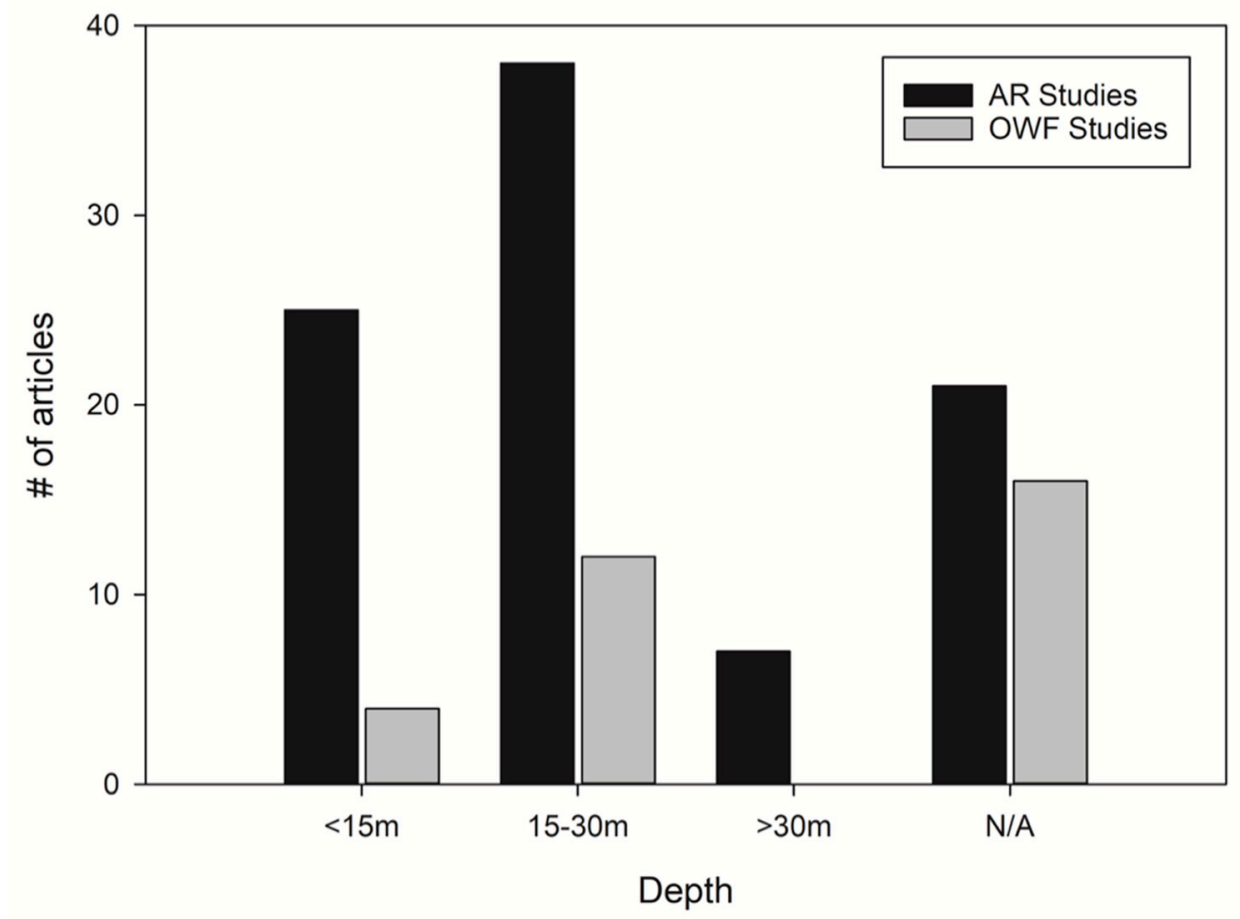

Figure 6. Mean water depths of artificial reef (AR) and offshore wind farm (OWF) structures. Some papers are included in multiple categories, because they studied more than one structure, located at different water depths. "N/A" means that the water depth was not specified in the articles.

\subsection{Effects of ARs and OWFs on Fish Abundance}

Provision of food [59,60], spawning [61] and shelter opportunities [62] by artificial structures are among the main themes dominating the literature, causing changes in fish abundance, biodiversity and distribution. In general, the vast majority of the AR studies (94\%) reported that fish abundance and biodiversity increased or was unaffected by AR deployment. More specifically, $49 \%$ of the literature reported locally increased fish abundances after AR deployment, while $31 \%$ found an increase in species richness in the AR area. Remaining papers did not report on the matter or recorded non-significant differences. Similarly, about half of the OWF literature (46\%) also reported increases in fish abundance. Specifically, fish abundance was consistently higher near the OWF foundations compared to reference areas [63-67]. This was particularly the case for species associated with rocky substratum [68], but occasionally it also extended to soft-bottom species when sampling the sandy areas within an OWF [69]. There was evidence of locally increased fish abundance for at least eight fish species in the OWF literature: Atlantic cod (Gadus morhua), European eel (Anguilla anguilla), goldsinny wrasse (Ctenolabrus rupestris), pouting (Trisopterus lucas), rock gunnel (Pholis gunnellus), shorthorn sculpin (Myoxocephalus scorpius), sole (Solea solea), striped red mullet (Mullus surmuletus), and whiting (Merlangius merlangus) $[35,65,68-71]$. Reubens et al. [70] found an average density of 14 pouting individuals per $\mathrm{m}^{2}$ on the scour protection, yielding an estimated local population of 22,000 pouting individuals around one wind turbine foundation. It is important to note, however, that the results reflect case studies and not necessarily general findings.

Only $38 \%$ of OWF papers reported on changes in fish diversity, however, $40 \%$ of those (i.e., $15 \%$ of total) indicated that scour protection elevated fish diversity compared to neighbouring control areas [72,73]. Only one OWF study reported lower species diversity. Specifically, Wilhelmsson et al. [64] found lower diversity of demersal fish around the turbine foundations compared to the seabed 1 to $20 \mathrm{~m}$ away. Conversely, a few studies indicated that a range of soft-bottom species were unaffected by the scour protection $[65,74]$. For example, Langhamer et al. [75] found that the abundance of viviparous eelpout (Zoarces viviparous) was unaffected by an OWF in Sweden. Similarly, the abundances of 
adult individuals of several pelagic species, including horse mackerel (Trachurus trachurus), mackerel (Scomber scombrus), herring (Clupea harengus) and sprat (Sprattus sprattus), were unaffected by the scour protection at a Dutch OWF [69].

A limited number of AR studies examined possible effects on soft-bottom species (e.g., flatfishes). For example, Fabi and Fiorentini [76] reported lower catch rates of the soft-bottom fish species (e.g., Chelidonichthys lucerna and Soleidae), compared to a control site, similar to Bombace et al. [77]. In relation to OWF, $19 \%$ of the studies included data on the impact on soft-bottom species. At Block Island Wind Farm, off Rhode Island in US, a study of seven flatfish species revealed no negative impacts [78]. On the contrary, Lindeboom et al. [65] reported a significant decrease in the soft-bottom species lesser weever (Echiichthys vipera) 2 years after construction of a Dutch OWF. Krone et al. [68] also reported low abundances of species associated with soft-bottom habitat, including species of Gobiidae and Callionymus spp., near the scour protection of a German OWF. Similar OWF-related trends have also been observed for flatfish species, including dab (Limanda limanda), sole, and solenette (Buglossidium luteum) [69].

\section{Discussion}

Although few countries have investigated both AR and OWF, this review identified overlap between AR studies and OWF studies in terms of water depth and materials, indicating that knowledge from temperate AR studies may be used to guide designs of future OWFs. Collectively, AR and OWF studies often observed an increase in abundance and diversity of fish species associated with hard-bottom habitats. Hard-bottom habitats provide food, shelter and habitats for reproduction, supporting the hypothesis that scour protection may create a reef effect [65]. Whether the increase in abundance is due to attraction or production is yet to be determined, however, there is growing evidence of new production associated with OWFs $[64,72,79,80]$. By modifying the designs of future scour protection, a range of habitats may be supported, increasing the abundance of target species [81] and possibly influencing fisheries via various mechanisms, including spill-over effects [28-30].

\subsection{Fish Abundance, Biodiversity and Distribution Associated with ARs and OWFs}

Artificial structures (i.e., both ARs and OWFs) typically hold higher fish density and biomass [82-84], largely attributed to the form, complexity, area coverage [62] and/or food abundance [85]. The findings of this review collectively confirm that artificial structures often increase the abundance of hard-bottom species as well as fish diversity in the local area. In some instances, however, artificial structures have no apparent reef effect for certain fish species, meaning that there is no noticeable increase or decrease for a given species. For example, abundances of adult individuals of several pelagic species, including horse mackerel, mackerel, herring, and sprat were unaffected by the presence of scour protection [69]. While adult individuals of pelagic species seemed unaffected by scour protection, they may still utilize scour protection as spawning or rearing habitat. Hard-bottom substrates are often important for the spawning of herring [86-89], suggesting that scour protection could have similar function. The loss of soft-bottom substrate arising from OWF installations may occasionally decrease the abundance of soft-bottom fish species $[65,68,69]$; however, due to the small amount of area covered by scour protection within an OWF (approximately $0.8 \%$ ), possible negative impacts are considered insignificant at the population level as indicated by previous studies $[69,73]$. Even though scour protection may have negative effects on soft-bottom species at the local scale, the effects should be evaluated at larger spatial scales and related to fish population sizes and movements.

\subsection{Attraction Versus Production}

There are mainly two hypotheses aiming to explain the increased fish abundance in artificial structures [90]. Firstly, the attraction hypothesis presumes that fish simply aggregate at the installations from the surrounding environment, without a net increase in the population of the larger area. Secondly, the production hypothesis suggests that the carrying capacity of the ecosystem increases because of 
the artificial structures. According to the second hypothesis, fish growth, reproduction and/or survival is elevated in the area, resulting in population enhancement, eventually contributing to an increase in the net production, both for biomass and abundance [90,91].

While there is growing evidence of increased fish abundance associated with OWFs, it remains unclear whether fish are simply attracted from surrounding areas or if the OWF facilitates fish production. Recent studies have highlighted the importance of increased production associated with ARs [92-94]. For example, Roa-Ureta et al. [94] predicted a 35\% increase in the carrying capacity for Diplodus vulgaris 4 years after ARs deployment, indicating new production. In terms of OWFs, several studies have suggested that OWFs act as nursery grounds and therefore, facilitate new fish production at the local scale $[64,72,79,80]$. In contrast, Wilson et al. [95] suggested that OWF foundations attract species from neighbouring areas, and Bergström et al. [35] concluded that elevated local abundance or diversity of fish near OWF foundations was due to a change in fish distribution, rather than a result of increased productivity.

The attraction versus production debate remains unresolved in most cases and the outcome of the debate relies upon an array of factors. The responses towards introduced hard substrata may vary among species, environments, locations, and age-specific requirements [90], while reef design characteristics, such as location, materials, size and number of units, also influence fish responses [91]. It is increasingly recognized that attraction and production effects are not mutually exclusive but should be considered as the two ends of a continuum [93,96-98].

\subsection{Community Changes Associated with ARs and OWFs}

Adding hard substrate may alter ecosystems in ways that benefit some species more than others $[35,99]$. For example, based on hydrodynamic modelling, introduced substrates from OWFs and ARs may increase the settlement of jellyfish polyps, potentially leading to jellyfish blooms [100,101]. This can affect fish species, as jellyfish compete with planktivorous fish and may forage on fish larvae [100]. OWFs may also attract fish species that would not naturally reside in the area [64]. For example, goldsinny wrasse and grey triggerfish (Balistes capriscus) were observed in Dutch OWFs, where they had not been recorded previously [69].

Non-indigenous fouling species, possibly invasive, may also utilize hard substrates associated with OWFs and ARs in soft-bottom environments [102]. Accordingly, OWFs may act as stepping-stones [103], enabling species to spread over large distances through a series of short-distance colonization events [63,102,104]; this may be particularly relevant for species like Jassa spp. that lack a distinct planktonic larval stage [104]. Due to the stepping-stone effect, sequential establishment of non-indigenous fouling species may occur rapidly on newly established OWF foundations [65,102]. Considering ocean warming, the placement of new hard substrata on the seascape may also facilitate the poleward expansion of non-indigenous species [105-107]. Observed non-indigenous species on OWF foundations include the Japanese oyster (Crassostrea gigas) and amphipods Jassa marmorata, Caprella mutica, and Caprella linearis $[63,65,108,109]$. In the Belgian part of the North Sea, 10 non-indigenous fouling macrobenthic species were identified on OWFs foundations [102]. OWF sites may also provide settlement habitat for pelagic larval particles that would otherwise have been unsuccessful in the area [110].

\subsection{Scour Protection Functioning as An AR}

Reviewed literature suggests that OWFs provide similar functions for marine organisms as ARs $[18,64,65,69-71,79,111,112]$ and OWF foundations have even been termed Windmill Artificial Reefs (WARs) [71,113]. These structures act as ARs by providing habitat, food, shelter and spawning opportunities, leading to the aggregation of various fish species around the foundations [65]. Importantly, scour protection enhances the habitat complexity and thereby augments the reef effect, as highlighted by previous studies $[29,70,95,112,113]$. 


\subsubsection{Food Provision}

OWFs often increase the local food availability for fish. For example, Leonhard and Pedersen [109] estimated that the scour protection at a Danish OWF provided a 50-fold increase in the local food availability for fish, compared to the previously sandy area. The uneven and coarse surfaces of scour protection and foundations allow sessile, fouling organisms to settle and provide food for various fish species $[66,114,115]$. To examine the provision of prey items by scour protection, De Troch et al. [66] profiled the energy levels of Atlantic cod and pouting caught just above the scour protection. The study found that the scour protection provided both species with sufficient energy reserves to grow and/or reproduce [66]. Moreover, stomach analyses performed on pouting aggregating near scour protection found a preference for hard substrate prey, amphipod Jassa herdmani and porcelain crab Pisidia longicornis, the dominating epifauna on the OWF foundations $[70,113]$. Although further studies are needed, these findings suggest that scour protection may provide feeding opportunities for a variety of fish species.

\subsubsection{Shelter}

The layer of boulders and rocks commonly used for scour protection creates crevices that provide hiding opportunities for fish and other fauna [113], consistent with similar mechanisms occurring in natural boulder reefs [116]. Video footage and diving surveys revealed commercial species such as Atlantic cod and pouting utilizing crevices associated with scour protection for shelter $[65,70]$. Moreover, acoustic telemetry demonstrated that Atlantic cod exhibit strong residency, high site fidelity and habitat selectivity towards OWF foundations with scour protection [71]. Therefore, scour protection may serve as a potential fish refuge and shelter from predators and strong currents, similar to ARs.

\subsubsection{Nursery}

Several studies have observed nursery functions of scour protection $[64,72,79,80]$. For example, Krone et al. [68] revealed that OWF foundations function as nursery grounds for the edible crab, Cancer pagurus. Andersson and Öhman [72] detected pregnant two-spotted goby females, as well as increased numbers of several size-classes associated with scour protection. On this basis, the authors hypothesized that the habitat created by the OWF facilitated recruitment and increased production. These indications signify that OWFs may function as nursery grounds, although the spatial extent is probably limited to the scour protection and the monopile alone.

\subsubsection{Distance between Artificial Habitats}

The location of OWFs may affect the composition and diversity of species assemblages that colonize and utilize the structures. A shorter distance to neighbouring hard substrata provides a greater likelihood of larvae and juveniles associated with local hard substrata to arrive and colonize [18]. A reef in a given area has a specific carrying capacity; often determined by reef size, in combination with the community composition (e.g., size of individuals and their foraging habits). To create the most productive ARs, it is important to consider the potential overlap with forage areas of neighbouring reef species. If the forage areas of two proximate ARs are overlapping, then the food availability and the potential yield from each AR may decrease [117]. Recently, Rosemond et al. [118] suggested a minimum buffer zone of $60 \mathrm{~m}$ to $120 \mathrm{~m}$ between neighbouring ARs to optimize the fish habitat utilization. The proposed buffer zone aims to minimize attraction from proximate reefs, maximize food resource availability in soft-bottom habitats around the reef and increase the area for typical fish behaviours, such as reproduction and foraging. Similar buffer zones between scour protections within OWF are de facto in place, since design guidelines highlight that the optimal distance between adjacent monopiles and scour protections should be seven times the rotor diameter of each turbine, resulting in distances exceeding ca. $430 \mathrm{~m}$ between individual scour protections [119]. These observations suggest that individual scour protections function as individual reefs. 


\subsubsection{Reef Size}

Numerous studies have indicated that reef volume and coverage area are crucial design requirements for a successful AR. A typical scour protection has a high perimeter-to-area ratio, with a radius up to 20 meters from the monopile [34,35], elevated about 1.5m above the seabed [38] (Figure 1); this is equivalent to a reef with a volume of $471 \mathrm{~m}^{3}$. Smaller ARs (i.e., similar to the size of a scour protection) often have increased fish densities in comparison to larger ARs [82,120,121]. This observation, however, applies mainly for attraction and not necessarily for new production [121]. Champion et al. [122] developed a model to examine the relationship between AR size and foraging capacity. Their model predicted that highest per-capita food availability occurs when the AR is relatively small. Ogawa et al. [123] reported that productivity of an AR increases directly with reef size from $400 \mathrm{~m}^{3}$ and up to $4000 \mathrm{~m}^{3}$, indicating that the minimum effective AR size is $400 \mathrm{~m}^{3}$ [123,124]. These AR findings suggest that the volume of an individual scour protection may be adequate to function as a reef.

\subsection{Optimizing Scour Protection}

A fundamental objective of this review is to extract knowledge from AR designs and apply it to scour protection research with the aim to potentially enhance favourable ecological functions. Even though the ultimate purpose of scour protection is to prevent the scouring of sediment (Figure 1), scour protection may also provide preferred habitats for several species [112]. The level of complexity, the distance between artificial structures, as well as the building material and water depth are the primary characteristics that determine the efficacy of an artificial structure in terms of supporting fish abundance and biodiversity $[12,112,118]$.

\subsubsection{Structural Complexity}

Previous studies have observed a positive correlation between the structural complexity of ARs and fish diversity and abundance [62,125]. Typically, larger fish require larger crevices, while smaller fish prefer smaller crevices [126]. A heterogeneous structure with a variety of crevice sizes and shapes may augment desired reef effects by elevating habitat heterogeneity, allowing a variety of fish species and life stages to utilize the area [34]. Feeding efficiency and growth of fish are maximized at intermediate levels of structural complexity, since very dense structures may hinder foraging [127]. Required crevice variety may be achieved with the use of mixed-sized blocks or boulders that are adjusted to the preferred shelter size for targeted species. In this fashion, scour protection design may be tailored to certain species or life stages.

The level of complexity can also be adjusted by the number of holes and crevices present in the applied material. For example, concrete modules with two holes may have a higher species abundance than simpler modules without holes [62]. Purposefully designed concrete reef units, also known as Reef Balls ${ }^{\circledR}$, have 25 to 40 holes in a hollow centre [112]. Reef Balls ${ }^{\circledR}$ are used as coastal defence structures and may also function as scour protection structures [112]. For a scour protection area of ca. $440 \mathrm{~m}^{2}$, a single layer of $169 \operatorname{Reef~Balls}^{\circledR}$ is required to protect one monopile [112]. The projected carrying capacity of a Reef Ball ${ }^{\circledR}$ is approximately $385 \mathrm{~kg}$ of fish within a year, suggesting that the annual carrying capacity of a scour protection may approach $65,000 \mathrm{~kg}[29,112]$. Although further research is required, these studies indicate that the structural complexity of scour protections may be elevated to enhance fish abundance and may even be tailored to certain fish sizes and life stages.

\subsubsection{Materials}

Different species settle on disparate substrates [128], suggesting that substrates may be tailored to suit target species. Rock is the most commonly used material for scour protection (Figure 5), because it is strong, stable, cost-efficient, erosion resistant, and suitable for benthic flora and fauna settlement. Nonetheless, concrete-gravel aggregate may be more suitable for design manipulations [129,130]. In addition, 
a single scour protection may include various materials, such as boulders, gravel and synthetic fronds to replicate a natural range of habitats and further increase habitat heterogeneity [81,112]. While synthetic fronds alone provide less surface area and space for colonization, they mimic vegetation and may provide additional ecological functions when combined with other types of scour protection [29].

\subsubsection{Enhancing Ecological Function}

Although the large-scale effects of OWFs on marine ecosystems remain uncertain $[69,73]$ and several studies have revealed negative effects of OWFs [131-133], the present review identified a range of ecosystem functions that might be enhanced by modifying the foundation of OWFs and the scour protection in particular (Figure 7). The conceptual illustration (Figure 7) is not exhaustive and it remains crucial to develop and test structural manipulations of scour protection designs to achieve favourable outcomes.

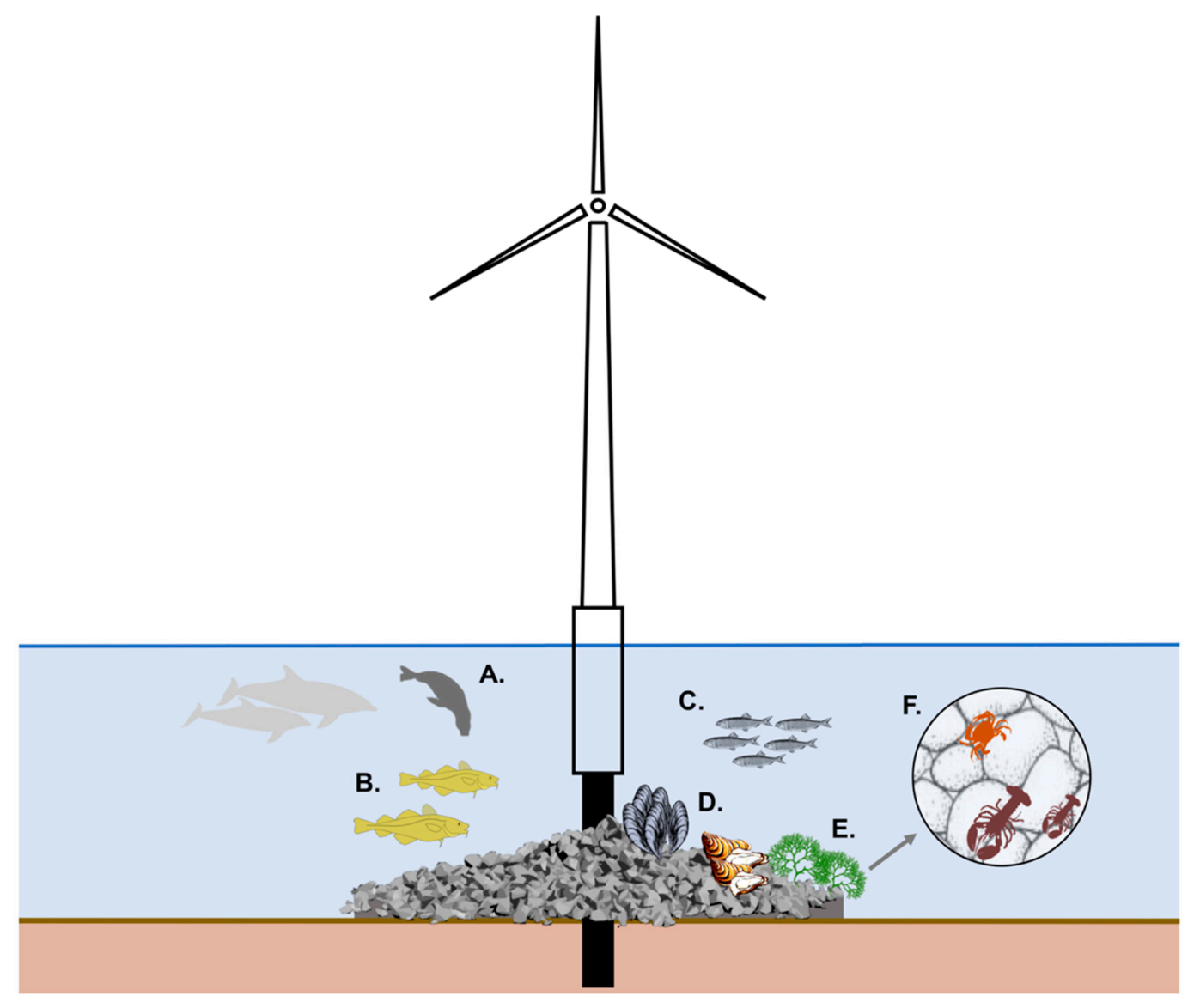

Figure 7. Conceptual illustration of offshore wind turbine and proposed ecological functions of scour protection. Reviewed evidence reveals that scour protection may provide food, shelter and reproduction grounds for fish, as well as settlement grounds for bivalves and macro algae. Examples show species that could benefit from improved scour protection designs: (A) Marine mammal feeding grounds [134]; (B) Atlantic cod, utilizing scour protection structures [71]; (C) Atlantic herring, utilizing scour protection for spawning [89]; (D) Mussel and oyster banks [135]; (E) Macro algal restoration [136,137]; (F) Shelter for shellfish [91].

Mammalian and fish apex predators may utilize OWFs for foraging; GPS tracking of two seal species (Phoca vitulina and Halichoerus grypus) in the North Sea indicated foraging close to the OWF foundations [134] (Figure 7A). Similarly, significantly higher occurrence of harbour porpoises was recorded inside a Dutch OWF compared to reference areas, partly attributed to increased food availability [138]. Various fish species may exhibit strong residency at OWF foundations with scour 
protection [71] (e.g., Atlantic cod; Figure 7B), which are also included in the diet of the two seal species $[139,140]$. This indicates that modified scour protection designs enhancing fish abundance could translate into benefits for a range of apex predators.

Rough surface texture in the materials used for reef construction can enhance benthic settlement $[115,141,142]$ (Figure 7D,E). Orientation of surfaces also plays an important role; bivalves, hydroids and barnacles mainly prefer colonizing vertical surfaces [135] (Figure 7D). High-vertical relief structures often support fish recruitment [143] and planktivore abundances, possibly by creating suitable hydrodynamic conditions [64]. Therefore, combined manipulations of materials and orientations may incite the growth of specific assemblages (Figure 7D,E). This may even be extended to setting up multi-use systems on OWFs, including, for example, mussel cultivation (Figure 7D).

Moreover, the macroalgal colonization of scour protection may be augmented using macroalgae restoration techniques $[136,137,144]$, as macroalgae has been shown to influence the composition and abundance of fish species on rocky habitats [145]. Verdura et al. [136] developed a relevant novel technique to restore patches of the canopy-forming alga Cystoseira barbata, while Fredriksen et al. [137] developed a method to restore kelp forests using rocks (Figure 7E). Macro algae growth may also support fish reproduction (Figure 7C). For example, in the Baltic Sea, herring select red algae Furcellaria lumbricalis and Polysiphonia fucoides as spawning substrate [89] (Figure 7C,E). This function requires that scour protection is in the photic zone, requiring shallow water OWFs. Such cases exist, however, including the "Horns Rev 1" OWF in the North Sea, which is situated at water depths between $6.5-13.5 \mathrm{~m}$ [73].

Shelter availability for shellfish species, such as the European lobster, Homarus gammarus, and C. pagurus, may create a demographic bottleneck [91]. Scour protection optimizations in favour of the European lobster could include size, shape, number of shelter entrances, and substrate $[146,147]$ (Figure 7F). Typically, adult lobsters and crayfish select crevices that have entrances analogous to their body size [148], while juveniles (carapace length, $\mathrm{CL}<35 \mathrm{~mm}$ ) are active burrowers and find shelter in soft substrates [149]. Barry and Wickins [149] proposed a mathematical model to estimate the best rock size combination to produce holes suitable for individuals with CL between $38-145 \mathrm{~mm}$. The model estimated that a 10-size rock solution (ranging from 40 to $3000 \mathrm{~mm}$ radius) produced the best results. Even though their model is a simplified version of reality, because the modelled rocks are spherical and therefore result in a denser packing than what might occur naturally, the model may still provide rough recommendations for the optimal rock size combination for scour protection designs (Figure 7F). If specific lobster sizes are targeted, the following simplified equation (1) could be used to calculate the appropriate rock size radius $(r)$ that will create the required target hole radius $(x)$ [149]:

$$
x=0.15 r
$$

For example, assuming that the rocks are spherical and homogenous in size, rocks with a radius of $1078 \mathrm{~mm}$ should be used to benefit lobsters with a CL of $145 \mathrm{~mm}$ [149]. To the best of our knowledge, preferred shelter sizes have not been quantified for fish, although such data could prove valuable to tailor scour protection designs for specific fish species and life stages.

\subsection{Advancing the Field}

Soft-bottom species might be vulnerable when hard substrata (e.g., foundations) are introduced in their ecosystem, because soft-bottom habitat is eliminated. Due to conflicting results, further studies are required to determine the impact of scour protection on soft-bottom species. Likewise, edge and transition zone effects [150-155], as well as community recovery models [156-158] should also be taken into consideration. Given the complexity of patchy habitats induced by scour protection, such studies may reveal unique ecological conditions existing in the transition zones between scour protection and soft-bottom habitats, as well as how soft-bottom species recover after partial loss of their habitat. 
To date, no empirical studies have examined ecological effects of different scour protection configurations. It is crucial to identify the size, shape, height, orientation, and material that provide most support for targeted ecosystem functions and services. The use of assorted scour protection materials should also receive further attention. Future studies should test concrete (possibly in Reef Ball ${ }^{\circledR}$ configuration) as an alternative material for scour protection. Further studies on preferred shelter dimensions for fishes are also needed to predict the optimal rock size for scour protections to provide ideal habitats for target species. Coastal defence structures have also been shown to offer opportunities for supporting ecological functions [11,159]. Even though these are not offshore structures, foundation designs of coastal OWFs could possibly benefit from coastal-defence knowledge [11,159]. This knowledge remains to be tested and integrated into cases where OWFs are being deployed in coastal areas.

Many OWF studies concern areas that are de facto no-fishing zones, since trawling and other fishing activities often are prohibited within a radius from the structures. These no-take conditions essentially create a marine-protected area that may increase the abundance of fish in neighbouring areas through spill-over effect [28-30,160]. The spill-over could be harvested by sustainable fisheries, but the topic has received limited attention. The main knowledge gap is estimating how much additional fish biomass is added to the ecosystem (at a larger scale) due to the presence and design of scour protection. Mounting evidence suggests spill-over effects of marine protected areas [161,162], but it remains unknown to what degree the effects depend on scour protections inside OWFs.

Existing evidence indicates that OWFs cause little to no effects on fish communities on a large spatial scale; however, due to the expected massive increase in OWFs [18,19], the scale of OWF effects is likely to expand over the coming years. With increased OWF development, effects of scour protection could reach a tipping point (i.e., induce a marine regime shift) $[163,164]$, where a certain density of scour protections may have significant effects on large-scale fish communities.

Apart from the scour protection, effects of the monopiles (or equivalent structures) should also be considered when determining changes in biodiversity and species abundance, as the community composition of the fouling fauna may differ along a depth gradient on a monopile [165]. Monopiles are, however, considered difficult to manipulate, opposite to the scour protection, and were therefore excluded from the present review. Interestingly, monopiles may attract mid-water forage species $[64,69]$ and associated predators, pointing to similar effects recorded at oil and gas platforms [15,166-169]. There are clearly interactions between these mid-water species and the species linked to scour protection, which should be further explored for a better understanding of community changes.

Lastly, when the production life of offshore infrastructure is over, current international policies call for removal of the structures. This type of decommissioning, however, could result in loss of marine habitat, especially considering species benefitting from OWFs $[16,99,170]$. Before decommissioning of the first OWF in the world (Vindeby, Denmark), the associated environmental impact assessment indicated that the removal of the foundation could reduce the local Atlantic cod abundance [171]. The impact on Atlantic cod was not attributed to the foundation removal activities per se, but rather to the loss of reef habitat in the area, after eliminating the foundations [171]. Therefore, before removing OWF foundations, reefing options may be considered [172,173]. An alternative to removal could be the "renewables-to-reefs" program, in which the foundation is partially removed, leaving the scour protection intact on the seafloor [174,175]. Modifying scour protection designs to favour fish abundance and diversity may amplify interests in keeping parts of the foundation intact during decommissioning.

\section{Conclusions}

This review is the first to transfer knowledge from AR studies to scour protection designs. Specifically, the review synthesized the effects of ARs and scour protection on fish biota and suggested approaches for enhancing the ecological function of scour protection. Overall, the vast majority of both AR and OWF studies report increases in fish abundance and diversity within the local area. Current evidence suggests that fish species of both high and low commercial value utilize the hard substrata that 
scour protection adds to the marine environment. This review has identified several scour protection manipulations that could influence abundance and diversity of marine species. By modifying future scour protection designs, fish abundance and diversity may be enhanced. As such, scour protection designs may be tailored to commercial species or threatened species. Further empirical research is needed to explore and test new and innovative scour protection designs, with the ultimate goal of creating scour protections that support marine goods and ecosystem services.

Author Contributions: Conceptualization, J.C.S.; methodology, J.C.S. and M.Z.; validation, J.C.S. and M.Z.; formal analysis, M.G.; investigation, M.G. and M.Z.; resources, J.C.S.; data curation, M.G.; writing-original draft preparation, M.G. and M.Z.; writing-review and editing, M.G. and J.C.S.; visualization, M.G.; supervision, J.C.S.; project administration, J.C.S.; funding acquisition, J.C.S. All authors have read and agreed to the published version of the manuscript.

Funding: This research was partly funded by the European Maritime and Fisheries Fund (grant number: 33113-B-16-057) and Vattenfall.

Acknowledgments: We sincerely thank the anonymous reviewers for their constructive and valuable comments.

Conflicts of Interest: The authors declare no conflict of interest. The funders had no role in the design of the study; in the collection, analyses, or interpretation of data; in the writing of the manuscript, or in the decision to publish the results.

\section{References}

1. Halpern, B.S.; Walbridge, S.; Selkoe, K.A.; Kappel, C.V.; Micheli, F.; D'Agrosa, C.; Bruno, J.F.; Casey, K.S.; Elbert, C.; Fox, H.E.; et al. A Global Map of Human Impact on Marine Ecosystems. Science 2008, 319, 948-953. [CrossRef]

2. Halpern, B.S.; Longo, C.; Hardy, D.; McLeod, K.L.; Samhouri, J.F.; Katona, S.K.; Kleisner, K.; Lester, S.E.; Oleary, J.; Ranelletti, M.; et al. An index to assess the health and benefits of the global ocean. Nature 2012, 488, 615-620. [CrossRef] [PubMed]

3. Waltham, N.J.; Connolly, R.M. Global extent and distribution of artificial, residential waterways in estuaries. Estuar. Coast. Shelf Sci. 2011, 94, 192-197. [CrossRef]

4. Dafforn, K.A.; Glasby, T.M.; Airoldi, L.; Rivero, N.K.; Mayer-Pinto, M.; Johnston, E.L. Marine urbanization: An ecological framework for designing multifunctional artificial structures. Front. Ecol. Environ. 2015, 13, 82-90. [CrossRef]

5. Heery, E.C.; Hoeksema, B.W.; Browne, N.K.; Reimer, J.D.; Ang, P.O.; Huang, D.; Friess, D.A.; Chou, L.M.; Loke, L.H.L.; Saksena-Taylor, P.; et al. Urban coral reefs: Degradation and resilience of hard coral assemblages in coastal cities of East and Southeast Asia. Mar. Pollut. Bull. 2018, 135, 654-681. [CrossRef]

6. Bulleri, F.; Chapman, M.G. The introduction of coastal infrastructure as a driver of change in marine environments. J. Appl. Ecol. 2010, 47, 26-35. [CrossRef]

7. Bishop, M.J.; Mayer-Pinto, M.; Airoldi, L.; Firth, L.B.; Morris, R.L.; Loke, L.H.L.; Hawkins, S.J.; Naylor, L.A.; Coleman, R.A.; Chee, S.Y.; et al. Effects of ocean sprawl on ecological connectivity: Impacts and solutions. J. Exp. Mar. Biol. Ecol. 2017, 492, 7-30. [CrossRef]

8. Heery, E.C.; Bishop, M.J.; Critchley, L.P.; Bugnot, A.B.; Airoldi, L.; Mayer-Pinto, M.; Sheehan, E.V.; Coleman, R.A.; Loke, L.H.L.; Johnston, E.L.; et al. Identifying the consequences of ocean sprawl for sedimentary habitats. J. Exp. Mar. Biol. Ecol. 2017, 492, 31-48. [CrossRef]

9. Bortone, S.A.; Seaman, W. Technology for the creation of aquatic habitats and their evaluation in fisheries ecosystems. Fish. Sci. 2002, 68, 1677-1682. [CrossRef]

10. Seaman, W. Artificial habitats and the restoration of degraded marine ecosystems and fisheries. Hydrobiologia 2007, 580, 143-155. [CrossRef]

11. Firth, L.B.; Thompson, R.C.; Bohn, K.; Abbiati, M.; Airoldi, L.; Bouma, T.J.; Bozzeda, F.; Ceccherelli, V.U.; Colangelo, M.A.; Evans, A.; et al. Between a rock and a hard place: Environmental and engineering considerations when designing coastal defence structures. Coast. Eng. 2014, 87, 122-135. [CrossRef]

12. Baine, M. Artificial reefs: A review of their design, application, management and performance. Ocean Coast. Manag. 2001, 44, 241-259. [CrossRef]

13. Tessier, A.; Francour, P.; Charbonnel, E.; Dalias, N.; Bodilis, P.; Seaman, W.; Lenfant, P. Assessment of French artificial reefs: Due to limitations of research, trends may be misleading. Hydrobiologia 2015, 753, 1-29. [CrossRef] 
14. Reubens, J.T.; Braeckman, U.; Vanaverbeke, J.; Van Colen, C.; Degraer, S.; Vincx, M. Aggregation at windmill artificial reefs: CPUE of Atlantic cod (Gadus morhua) and pouting (Trisopterus luscus) at different habitats in the Belgian part of the North Sea. Fish. Res. 2013, 139, 28-34. [CrossRef]

15. Fujii, T. Potential influence of offshore oil and gas platforms on the feeding ecology of fish assemblages in the North Sea. Mar. Ecol. Prog. Ser. 2016, 542, 167-186. [CrossRef]

16. Fowler, A.M.; Jørgensen, A.; Coolen, J.W.P.; Brabant, R.; Rumes, B.; Degraer, S. The ecology of infrastructure decommissioning in the North Sea: What we need to know and how to achieve it. ICES J. Mar. Sci. 2019, 77, 1109-1126. [CrossRef]

17. Edney, J.; Spennemann, D.H.R. Can Artificial Reef Wrecks Reduce Diver Impacts on Shipwrecks? The Management Dimension. J. Marit. Archaeol. 2015, 10, 141-157. [CrossRef]

18. Petersen, J.K.; Malm, T. Offshore Windmill Farms: Threats to or Possibilities for the Marine Environment. Ambio 2006, 35, 75-80. [CrossRef]

19. Ramírez, L.; Fraile, D.; Brindley, G. Offshore wind in Europe-Key trends and statistics 2019; WindEurope. 2020, pp. 1-38. Available online: https://windeurope.org/about-wind/statistics/offshore/european-offshorewind-industry-key-trends-statistics-2019/ (accessed on 8 May 2020).

20. Drewitt, A.L.; Langston, R.H.W. Assessing the impacts of wind farms on birds. Ibis 2006, 148, $29-42$. [CrossRef]

21. Thaxter, C.B.; Buchanan, G.M.; Carr, J.; Butchart, S.H.M.; Newbold, T.; Green, R.E.; Tobias, J.A.; Foden, W.B.; O'Brien, S.; Pearce-Higgins, J.W. Bird and bat species' global vulnerability to collision mortality at wind farms revealed through a trait-based assessment. Proc. R. Soc. B 2017, 284, 20170829. [CrossRef]

22. Wahlberg, M.; Westerberg, H. Hearing in fish and their reactions to sounds from offshore wind farms. Mar. Ecol. Prog. Ser. 2005, 288, 295-309. [CrossRef]

23. Madsen, P.T.; Wahlberg, M.; Tougaard, J.; Lucke, K.; Tyack, P. Wind turbine underwater noise and marine mammals: Implications of current knowledge and data needs. Mar. Ecol. Prog. Ser. 2006, 309, 279-295. [CrossRef]

24. Brandt, M.J.; Dragon, A.C.; Diederichs, A.; Bellmann, M.A.; Wahl, V.; Piper, W.; Nabe-Nielsen, J.; Nehls, G. Disturbance of harbour porpoises during construction of the first seven offshore wind farms in Germany. Mar. Ecol. Prog. Ser. 2018, 596, 213-232. [CrossRef]

25. Öhman, M.C.; Sigray, P.; Westerberg, H. Offshore windmills and the effects of electromagnetic fields on fish. AMBIO 2007, 36, 630-633. [CrossRef]

26. Bray, L.; Reizopoulou, S.; Voukouvalas, E.; Soukissian, T.; Alomar, C.; Vázquez-Luis, M.; Deudero, S.; Attrill, M.J.; Hall-Spencer, J.M. Expected effects of offshore wind farms on Mediterranean Marine Life. J. Mar. Sci. Eng. 2016, 4, 18. [CrossRef]

27. Langhamer, O.; Wilhelmsson, D. Colonisation of fish and crabs of wave energy foundations and the effects of manufactured holes-A field experiment. Mar. Environ. Res. 2009, 68, 151-157. [CrossRef]

28. Punt, M.J.; Groeneveld, R.A.; van Ierland, E.C.; Stel, J.H. Spatial planning of offshore wind farms: A windfall to marine environmental protection? Ecol. Econ. 2009, 69, 93-103. [CrossRef]

29. Langhamer, O. Artificial reef effect in relation to offshore renewable energy conversion: State of the art. Sci. World J. 2012, 2012, 386713. [CrossRef]

30. Ashley, M.C.; Mangi, S.C.; Rodwell, L.D. The potential of offshore windfarms to act as marine protected areas-A systematic review of current evidence. Mar. Policy 2014, 45, 301-309. [CrossRef]

31. den Boon, J.; Sutherland, J.; Whitehouse, R. Scour behaviour and scour protection for monopile foundations of offshore wind turbines. In Proceedings of the European Wind Energy Conference \& Exhibition (EWEC), London, UK, 22-25 November 2004; Volume 14, pp. 1-14.

32. Sumer, B.M.; Fredsøe, J. The Mechanics of Scour in the Marine Environment; World Scientific: River Edge, NJ, USA, 2002; Volume 17, pp. 1-552.

33. Atalah, J.; Fitch, J.; Coughlan, J.; Chopelet, J.; Coscia, I.; Farrell, E. Diversity of demersal and megafaunal assemblages inhabiting sandbanks of the Irish Sea. Mar. Biodivers. 2013, 43, 121-132. [CrossRef]

34. Hammar, L.; Andersson, S.; Rosenberg, R. Adapting offshore wind power foundations to local environment; Swedish Environmental Protection Agency; 2010; Report no. 6367. pp. 1-86. Available online: http: //www.naturvardsverket.se/documents/publikationer/978-91-620-6367-2.pdf (accessed on 8 May 2020).

35. Bergström, L.; Sundqvist, F.; Bergström, U. Effects of an offshore wind farm on temporal and spatial patterns in the demersal fish community. Mar. Ecol. Prog. Ser. 2013, 485, 199-210. [CrossRef] 
36. De Vos, L.; De Rouck, J.; Troch, P.; Frigaard, P. Empirical design of scour protections around monopile foundations. Part 2: Dynamic approach. Coast. Eng. 2012, 60, 286-298. [CrossRef]

37. Liang, B.; Du, S.; Pan, X.; Zhang, L. Local scour for vertical piles in steady currents: Review of mechanisms, influencing factors and empirical equations. J. Mar. Sci. Eng. 2020, 8, 4. [CrossRef]

38. Whitehouse, R.J.S.; Harris, J.M.; Sutherland, J.; Rees, J. The nature of scour development and scour protection at offshore windfarm foundations. Mar. Pollut. Bull. 2011, 62, 73-88. [CrossRef]

39. Steffen, W.; Crutzen, P.J.; Mcneill, J. The Anthropocene: Are Humans Now Overwhelming the Great Forces of Nature? AMBIO 2007, 36, 614-621. [CrossRef]

40. Scheffers, B.R.; De Meester, L.; Bridge, T.C.L.; Hoffmann, A.A.; Pandolfi, J.M.; Corlett, R.T.; Butchart, S.H.M.; Pearce-Kelly, P.; Kovacs, K.M.; Dudgeon, D.; et al. The broad footprint of climate change from genes to biomes to people. Science 2016, 354, aaf7671. [CrossRef]

41. Bowman, D.M.J.S.; Garnett, S.T.; Barlow, S.; Bekessy, S.A.; Bellairs, S.M.; Bishop, M.J.; Bradstock, R.A.; Jones, D.N.; Maxwell, S.L.; Pittock, J.; et al. Renewal ecology: Conservation for the Anthropocene. Restor. Ecol. 2017, 25, 674-680. [CrossRef]

42. Maes, J.; Jacobs, S. Nature-Based Solutions for Europe's Sustainable Development. Conserv. Lett. 2017, 10, 121-124. [CrossRef]

43. Lenkeek, W.; Didderen, K.; Teunis, M.; Driessen, F.; Coolen, J.W.P.; Bos, O.G.; Vergouwen, S.A.; Raaijmakers, T.C.; de Vries, M.B.; van Koningsveld, M. Eco-friendly design of scour protection: potential enhancement of ecological functioning in offshore wind farms; Ministry of Economic Affairs, Department of Nature \& Biodiversity; 2017; Report no. 17-001. pp. 1-28. Available online: https://edepot.wur.nl/411374 (accessed on 8 May 2020).

44. Morris, R.L.; Porter, A.G.; Figueira, W.F.; Coleman, R.A.; Fobert, E.K.; Ferrari, R. Fish-smart seawalls: A decision tool for adaptive management of marine infrastructure. Front. Ecol. Environ. 2018, 16, 278-287. [CrossRef]

45. Strain, E.M.A.; Olabarria, C.; Mayer-Pinto, M.; Cumbo, V.; Morris, R.L.; Bugnot, A.B.; Dafforn, K.A.; Heery, E.; Firth, L.B.; Brooks, P.R.; et al. Eco-engineering urban infrastructure for marine and coastal biodiversity: Which interventions have the greatest ecological benefit? J. Appl. Ecol. 2018, 55, 426-441. [CrossRef]

46. Dafforn, K.A.; Mayer-Pinto, M.; Morris, R.L.; Waltham, N.J. Application of management tools to integrate ecological principles with the design of marine infrastructure. J. Environ. Manag. 2015, 158, 61-73. [CrossRef] [PubMed]

47. Pullin, A.S.; Stewart, G.B. Guidelines for systematic review in conservation and environmental management. Conserv. Biol. 2006, 20, 1647-1656. [CrossRef] [PubMed]

48. Papathanasopoulou, E.; Beaumont, N.; Hooper, T.; Nunes, J.; Queirós, A.M. Energy systems and their impacts on marine ecosystem services. Renew. Sustain. Energy Rev. 2015, 52, 917-926. [CrossRef]

49. Flávio, H.M.; Ferreira, P.; Formigo, N.; Svendsen, J.C. Reconciling agriculture and stream restoration in Europe: A review relating to the EU Water Framework Directive. Sci. Total Environ. 2017, 596-597, 378-395. [CrossRef] [PubMed]

50. Moher, D.; Libersti, A.; Tetzlaff, J.; Altman, D.G.; Group, T.P. Preferred Reporting Items for Systematic Reviews and Meta-Analyses: The PRISMA Statement. PLoS Med. 2009, 6, e1000097. [CrossRef]

51. Whitmarsh, S.K.; Fairweather, P.G.; Huveneers, C. What is Big BRUVver up to? Methods and uses of baited underwater video. Rev. Fish Biol. Fish. 2017, 27, 53-73. [CrossRef]

52. Støttrup, J.G.; Dahl, K.; Niemann, S.; Stenberg, C.; Reker, J.; Stamphøj, E.M.; Göke, C.; Svendsen, J.C. Restoration of a boulder reef in temperate waters: Strategy, methodology and lessons learnt. Ecol. Eng. 2017, 102, 468-482. [CrossRef]

53. Kristensen, L.D.; Støttrup, J.G.; Svendsen, J.C.; Stenberg, C.; Højbjerg Hansen, O.K.; Grønkjær, P. Behavioural changes of Atlantic cod (Gadus morhua) after marine boulder reef restoration: Implications for coastal habitat management and Natura 2000 areas. Fish. Manag. Ecol. 2017, 24, 353-360. [CrossRef]

54. Kayano, Y. Effects of artificial reefs and the acoustic-sound feeding method on the colonization of released grouper seedlings. Fish. Sci. 2002, 68, 1683-1686. [CrossRef]

55. Castège, I.; Milon, E.; Fourneau, G.; Tauzia, A. First results of fauna community structure and dynamics on two artificial reefs in the south of the Bay of Biscay (France). Estuar. Coast. Shelf Sci. 2016, 179, 172-180. [CrossRef] 
56. Carral, L.; Alvarez-Feal, J.C.; Tarrio-Saavedra, J.; Rodriguez Guerreiro, M.J.; Fraguela, J.Á. Social interest in developing a green modular artificial reef structure in concrete for the ecosystems of the Galician rías. J. Clean. Prod. 2018, 172, 1881-1898. [CrossRef]

57. Yang, Y.; Ji, T.; Lin, X.; Chen, C.; Yang, Z. Biogenic sulfuric acid corrosion resistance of new artificial reef concrete. Constr. Build. Mater. 2018, 158,33-41. [CrossRef]

58. Sánchez, S.; López-Gutiérrez, J.S.; Negro, V.; Esteban, M.D. Foundations in offshore wind farms: Evolution, characteristics and range of use. Analysis of main dimensional parameters in monopile foundations. J. Mar. Sci. Eng. 2019, 7, 441. [CrossRef]

59. Abecasis, D.; Bentes, L.; Lino, P.G.; Santos, M.N.; Erzini, K. Residency, movements and habitat use of adult white seabream (Diplodus sargus) between natural and artificial reefs. Estuar. Coast. Shelf Sci. 2013, 118, 80-85. [CrossRef]

60. Cresson, P.; Ruitton, S.; Harmelin-Vivien, M. Artificial reefs do increase secondary biomass production: Mechanisms evidenced by stable isotopes. Mar. Ecol. Prog. Ser. 2014, 509, 15-26. [CrossRef]

61. La Mesa, G.; Longobardi, A.; Sacco, F.; Marino, G. First Release of Hatchery Juveniles of the Dusky Grouper Epinephelus marginatus (Lowe, 1834) (Serranidae: Teleostei) at Artificial Reefs in the Mediterranean: Results from a Pilot Study. Sci. Mar. 2008, 72, 743-756. [CrossRef]

62. Hunter, W.R.; Sayer, M.D.J.J. The comparative effects of habitat complexity on faunal assemblages of northern temperate artificial and natural reefs. ICES J. Mar. Sci. 2009, 66, 691-698. [CrossRef]

63. Wilhelmsson, D.; Malm, T. Fouling assemblages on offshore wind power plants and adjacent substrata. Estuar. Coast. Shelf Sci. 2008, 79, 459-466. [CrossRef]

64. Wilhelmsson, D.; Malm, T.; Öhman, M.C. The influence of offshore windpower on demersal fish. ICES J. Mar. Sci. 2006, 63, 775-784. [CrossRef]

65. Lindeboom, H.J.; Kouwenhoven, H.J.; Bergman, M.J.N.; Bouma, S.; Brasseur, S.; Daan, R.; Fijn, R.C.; De Haan, D.; Dirksen, S.; Van Hal, R.; et al. Short-term ecological effects of an offshore wind farm in the Dutch coastal zone; A compilation. Environ. Res. Lett. 2011, 6, 035101. [CrossRef]

66. De Troch, M.; Reubens, J.T.; Heirman, E.; Degraer, S.; Vincx, M. Energy profiling of demersal fish: A case-study in wind farm artificial reefs. Mar. Environ. Res. 2013, 92, 224-233. [CrossRef] [PubMed]

67. Bergman, M.J.N.; Ubels, S.M.; Duineveld, G.C.A.; Meesters, E.W.G. Effects of a 5-year trawling ban on the local benthic community in a wind farm in the Dutch coastal zone. ICES J. Mar. Sci. 2015, 72, 962-972. [CrossRef]

68. Krone, R.; Dederer, G.; Kanstinger, P.; Krämer, P.; Schneider, C.; Schmalenbach, I. Mobile demersal megafauna at common offshore wind turbine foundations in the German Bight (North Sea) two years after deployment-Increased production rate of Cancer pagurus. Mar. Environ. Res. 2017, 123, 53-61. [CrossRef]

69. van Hal, R.; Griffioen, A.B.; van Keeken, O.A. Changes in fish communities on a small spatial scale, an effect of increased habitat complexity by an offshore wind farm. Mar. Environ. Res. 2017, 126, 26-36. [CrossRef] [PubMed]

70. Reubens, J.T.; Degraer, S.; Vincx, M. Aggregation and feeding behaviour of pouting (Trisopterus luscus) at wind turbines in the Belgian part of the North Sea. Fish. Res. 2011, 108, 223-227. [CrossRef]

71. Reubens, J.T.; Pasotti, F.; Degraer, S.; Vincx, M. Residency, site fidelity and habitat use of atlantic cod (Gadus morhua) at an offshore wind farm using acoustic telemetry. Mar. Environ. Res. 2013, 90, 128-135. [CrossRef]

72. Andersson, M.H.; Öhman, M.C. Fish and sessile assemblages associated with wind-turbine constructions in the Baltic Sea. Mar. Freshw. Res. 2010, 61, 642-650. [CrossRef]

73. Stenberg, C.; Støttrup, J.G.; van Deurs, M.; Berg, C.W.; Dinesen, G.E.; Mosegaard, H.; Grome, T.M.; Leonhard, S.B. Long-term effects of an offshore wind farm in the North Sea on fish communities. Mar. Ecol. Prog. Ser. 2015, 528, 257-265. [CrossRef]

74. van Deurs, M.; Grome, T.M.; Kaspersen, M.; Jensen, H.; Stenberg, C.; Sørensen, T.K.; Støttrup, J.; Warnar, T.; Mosegaard, H. Short- and long-term effects of an offshore wind farm on three species of sandeel and their sand habitat. Mar. Ecol. Prog. Ser. 2012, 458, 169-180. [CrossRef]

75. Langhamer, O.; Dahlgren, T.G.; Rosenqvist, G. Effect of an offshore wind farm on the viviparous eelpout: Biometrics, brood development and population studies in Lillgrund, Sweden. Ecol. Indic. 2018, 84, 1-6. [CrossRef]

76. Fabi, G.; Fiorentini, L. Comparison between an artificial reef and a control site in the Adriatic Sea: Analysis of four years of monitoring. Bull. Mar. Sci. 1994, 55, 538-558. 
77. Bombace, G.; Fabi, G.; Fiorentini, L.; Speranza, S. Analysis of The Efficacy of Artificial Reefs Located in Five Different Areas of the Adriatic Sea. Bull. Mar. Sci. 1994, 55, 559-580.

78. Wilber, D.H.; Carey, D.A.; Griffin, M. Flatfish habitat use near North America's first offshore wind farm. J. Sea Res. 2018, 139, 24-32. [CrossRef]

79. Reubens, J.T.; Degraer, S.; Vincx, M. The ecology of benthopelagic fishes at offshore wind farms: A synthesis of 4 years of research. Hydrobiologia 2014, 727, 121-136. [CrossRef]

80. Reubens, J.T.; Vandendriessche, S.; Zenner, A.N.; Degraer, S.; Vincx, M. Offshore wind farms as productive sites or ecological traps for gadoid fishes?-Impact on growth, condition index and diet composition. Mar. Environ. Res. 2013, 90, 66-74. [CrossRef]

81. Bat, L.; Sezgin, M.; Sahin, F. Impacts of OWF installations on fisheries: A Literature Review. J. Coast. Life Med. 2013, 1, 241-252.

82. Bohnsack, J.A.; Harper, D.E.; McClellan, D.B.; Hulsbeck, M. Effects of Reef Size on Colonization and Assemblage Structure of Fishes at Artificial Reefs Off Southeastern Florida, U.S.A. Bull. Mar. Sci. 1994, 55, 796-823.

83. Methratta, E.T.; Dardick, W.R.; Methratta, E.T.; Dardick, W.R. Meta-Analysis of Finfish Abundance at Offshore Wind Farms. Rev. Fish. Sci. Aquac. 2019, 27, 242-260. [CrossRef]

84. Yu, J.; Chen, P.; Tang, D.; Qin, C. Ecological effects of artificial reefs in Daya Bay of China observed from satellite and in situ measurements. Adv. Sp. Res. 2015, 55, 2315-2324. [CrossRef]

85. Fabi, G.; Manoukian, S.; Spagnolo, A. Feeding behavior of three common fishes at an artificial reef in the northern Adriatic Sea. Bull. Mar. Sci. 2006, 78, 39-56.

86. Aneer, G.; Nellbring, S. A SCUBA-diving investigation of Baltic herring (Clupea harengus membras L.) spawning grounds in the Asko-Landsort area, northern Baltic proper. J. Fish Biol. 1982, 21, 433-442. [CrossRef]

87. Johannessen, A. Recruitment studies of herring (Clupea harengus L.) in Lindaaspollene, western Norway. Fisk. Skr. Ser. Havundersøkelser 1986, 18, 139-240.

88. Kääriä, J.; Rajasilta, M.; Kurkilahti, M.; Soikkeli, M. Spawning bed selection by the Baltic herring (Clupea harengus membras) in the Archipelago of SW Finland. ICES J. Mar. Sci. 1997, 54, 917-923. [CrossRef]

89. Šaškov, A.; Šiaulys, A.; Bučas, M.; Daunys, D. Baltic herring (Clupea harengus membras) spawning grounds on the Lithuanian coast: Current status and shaping factors. Oceanologia 2014, 56, 789-804. [CrossRef]

90. Brickhill, M.J.; Lee, S.Y.; Connolly, R.M. Fishes associated with artificial reefs: Attributing changes to attraction or production using novel approaches. J. Fish Biol. 2005, 67, 53-71. [CrossRef]

91. Pickering, H.; Whitmarsh, D. Artificial reefs and fisheries exploitation: A review of the "attraction versus production" debate, the influence of design and its significance for policy. Fish. Res. 1997, 31, 39-59. [CrossRef]

92. Granneman, J.E.; Steele, M.A. Fish Growth, Reproduction, and Tissue Production on Artificial Reefs Relative to Natural Reefs. ICES J. Mar. Sci. 2014, 71, 2494-2504. [CrossRef]

93. Cresson, P.; Le Direach, L.; Rouanet, E.; Goberville, E.; Astruch, P.; Ourgaud, M.; Harmelin-Vivien, M. Functional traits unravel temporal changes in fish biomass production on artificial reefs. Mar. Environ. Res. 2019, 145, 137-146. [CrossRef]

94. Roa-Ureta, R.H.; Santos, M.N.; Leitão, F. Modelling long-term fisheries data to resolve the attraction versus production dilemma of artificial reefs. Ecol. Modell. 2019, 407, 108727. [CrossRef]

95. Wilson, J.C.; Elliott, M.; Cutts, N.D.; Mander, L.; Mendão, V.; Perez-Dominguez, R.; Phelps, A. Coastal and offshore wind energy generation: Is it environmentally benign? Energies 2010, 3, 1383-1422. [CrossRef]

96. Osenberg, C.W.; St. Mary, C.M.; Wilson, J.A.; Lindberg, W.J. A quantitative framework to evaluate the attraction-production controversy. ICES J. Mar. Sci. 2002, 59, S214-S221. [CrossRef]

97. Scarcella, G.; Grati, F.; Bolognini, L.; Domenichetti, F.; Malaspina, S.; Manoukian, S.; Polidori, P.; Spagnolo, A.; Fabi, G. Time-series analyses of fish abundance from an artificial reef and a reference area in the central-Adriatic Sea. J. Appl. Ichthyol. 2015, 31, 74-85. [CrossRef]

98. Schwartzbach, A.; Behrens, J.; Svendsen, J. Atlantic cod Gadus morhua save energy on stone reefs: Implications for the attraction versus production debate in relation to reefs. Mar. Ecol. Prog. Ser. 2020, 635, 81-87. [CrossRef]

99. Gill, A.B. Offshore renewable energy: Ecological implications of generating electricity in the coastal zone. J. Appl. Ecol. 2005, 42, 605-615. [CrossRef]

100. Janßen, H.; Augustin, C.B.; Hinrichsen, H.H.; Kube, S. Impact of secondary hard substrate on the distribution and abundance of Aurelia aurita in the western Baltic Sea. Mar. Pollut. Bull. 2013, 75, 224-234. [CrossRef] 
101. Makabe, R.; Furukawa, R.; Takao, M.; Uye, S.I. Marine artificial structures as amplifiers of Aurelia aurita s.l. blooms: A case study of a newly installed floating pier. J. Oceanogr. 2014, 70, 447-455. [CrossRef]

102. De Mesel, I.; Kerckhof, F.; Norro, A.; Rumes, B.; Degraer, S. Succession and seasonal dynamics of the epifauna community on offshore wind farm foundations and their role as stepping stones for non-indigenous species. Hydrobiologia 2015, 756, 37-50. [CrossRef]

103. Tidbury, H.; Taylor, N.; Van der Molen, J.; Garcia, L.; Posen, P.; Gill, A.; Lincoln, S.; Judd, A.; Hyder, K. Social network analysis as a tool for marine spatial planning: Impacts of decommissioning on connectivity in the North Sea. J. Appl. Ecol. 2020, 57, 566-577. [CrossRef]

104. Degraer, S.; Brabant, R. Offshore wind farms in the Belgian part of the North Sea: State of the art after two years of environmental monitoring; Royal Belgian Institute for Natural Sciences, Management Unit of the North Sea Mathematical Models, Marine Ecosystem Management Unit. 2009; pp. 1-287. Available online: https://tethys.pnnl.gov/publications/offshore-wind-farms-belgian-part-north-sea-state-art-after-twoyears-environmental (accessed on 8 May 2020).

105. Southward, A.J.; Hawkins, S.J.; Burrows, M.T. Seventy years' observations of changes in distribution and abundance of zooplankton and intertidal organisms in the western English Channel in relation to rising sea temperature. J. Therm. Biol. 1995, 20, 127-155. [CrossRef]

106. Stachowicz, J.J.; Terwin, J.R.; Whitlatch, R.B.; Osman, R.W. Linking climate change and biological invasions: Ocean warming facilitates nonindigenous species invasions. Proc. Natl. Acad. Sci. USA 2002, 99, 15497-15500. [CrossRef]

107. Walther, G.R.; Roques, A.; Hulme, P.E.; Sykes, M.T.; Pyšek, P.; Kühn, I.; Zobel, M.; Bacher, S.; Botta-Dukát, Z.; Bugmann, H.; et al. Alien species in a warmer world: Risks and opportunities. Trends Ecol. Evol. 2009, 24, 686-693. [CrossRef]

108. Coolen, J.W.P.; Lengkeek, W.; Degraer, S.; Kerckhof, F.; Kirkwood, R.J.; Lindeboom, H.J. Distribution of the invasive Caprella mutica Schurin, 1935 and native Caprella linearis (Linnaeus, 1767) on artificial hard substrates in the North Sea: Separation by habitat. Aquat. Invasions 2016, 11, 437-449. [CrossRef]

109. Leonhard, S.B.; Pedersen, J. Benthic Communities at Horns Rev Before, During and After Construction of Horns Rev Offshore Wind Farm-Annual Report 2005. Vattenfall 2006, 84, 134.

110. Adams, T.P.; Miller, R.G.; Aleynik, D.; Burrows, M.T. Offshore marine renewable energy devices as stepping stones across biogeographical boundaries. J. Appl. Ecol. 2014, 51, 330-338. [CrossRef]

111. Maar, M.; Bolding, K.; Petersen, J.K.; Hansen, J.L.S.; Timmermann, K. Local effects of blue mussels around turbine foundations in an ecosystem model of Nysted off-shore wind farm, Denmark. J. Sea Res. 2009, 62, 159-174. [CrossRef]

112. Wilson, J.C.; Elliott, M. The habitat-creation potential of offshore wind farms. Wind Energy 2009, 12, $203-212$. [CrossRef]

113. Reubens, J.T.; De Rijcke, M.; Degraer, S.; Vincx, M. Diel variation in feeding and movement patterns of juvenile Atlantic cod at offshore wind farms. J. Sea Res. 2014, 85, 214-221. [CrossRef]

114. Kerckhof, F.; Rumes, B.; Jacques, T.; Degraer, S.; Norro, A. Early development of the subtidal marine biofouling on a concrete offshore windmill foundation on the Thornton Bank (southern North Sea): First monitoring results. Underw. Technol. 2010, 29, 137-149. [CrossRef]

115. Hixon, M.A.; Brostoff, W.N. Substrate characteristics, fish grazing, and epibenthic assemblages off Hawaii. Bull. Mar. Sci. 1985, 37, 200-213.

116. Beisiegel, K.; Tauber, F.; Gogina, M.; Zettler, M.L.; Darr, A. The potential exceptional role of a small Baltic boulder reef as a solitary habitat in a sea of mud. Aquat. Conserv. Mar. Freshw. Ecosyst. 2019, 29, 321-328. [CrossRef]

117. Bortone, S.A.; Cody, R.P.; Turpin, R.K.; Bundrick, C.M. The impact of artificial-reef fish assemblages on their potential forage area. Ital. J. Zool. 1998, 65, 265-267. [CrossRef]

118. Rosemond, R.C.; Paxton, A.B.; Lemoine, H.R.; Fegley, S.R.; Peterson, C.H. Fish use of reef structures and adjacent sand flats: Implications for selecting minimum buffer zones between new artificial reefs and existing reefs. Mar. Ecol. Prog. Ser. 2018, 587, 187-199. [CrossRef]

119. Shen, W.Z.; Mikkelsen, R.F. Study on wind turbine arrangement for offshore wind farms. In Proceedings of the ICOWEOE-2011, Beijing, China, 31 October-2 November 2011.

120. Leitão, F.; Santos, M.N.; Erzini, K.; Monteiro, C.C. Fish assemblages and rapid colonization after enlargement of an artificial reef off the Algarve coast (Southern Portugal). Mar. Ecol. 2008, 29, 435-448. [CrossRef] 
121. Ambrose, R.F.; Swarbrick, S.L. Comparison of fish assemblages on artificial and natural reefs off the coast of southern California. Bull. Mar. Sci. 1989, 44, 718-733.

122. Champion, C.; Suthers, I.M.; Smith, J.A. Zooplanktivory is a key process for fish production on a coastal artificial reef. Mar. Ecol. Prog. Ser. 2015, 541, 1-14. [CrossRef]

123. Ogawa, S.; Takeuchi, R.; Hattori, H. An estimate for the optimum size of artificial reefs. Bull. Jpn. Soc. Fish. Oceanogr. 1977, 30, 39-45.

124. Bohnsack, J.A.; Sutherland, D.L. Artificial Reef Research: A Review with Recommendations for Future Priorities. Bull. Mar. Sci. 1985, 37, 11-39.

125. Charbonnel, E.; Serre, C.; Ruitton, S.; Harmelin, J.G.; Jensen, A. Effects of increased habitat complexity on fish assemblages associated with large artificial reef units (French Mediterranean coast). ICES J. Mar. Sci. 2002, 59, 208-213. [CrossRef]

126. Hixon, M.A.; Beets, J.P. Predation, Prey Refuges, and the Structure of Coral-Reef Fish Assemblages. Ecol. Monogr. 1993, 63, 77-101. [CrossRef]

127. Crowder, L.B.; Cooper, W.E. Habitat Structural Complexity and the Interaction Between Bluegills and Their Prey. Ecology 1982, 63, 1802-1813. [CrossRef]

128. Davis, K.L.; Coleman, M.A.; Connell, S.D.; Russell, B.D.; Gillanders, B.M.; Kelaher, B.P. Ecological performance of construction materials subject to ocean climate change. Mar. Environ. Res. 2017, 131, 177-182. [CrossRef]

129. Walker, B.K.; Henderson, B.; Spieler, R.E.; Beach, M.; Walker, B.K.; Henderson, B.; Spieler, R.E. Fish Assemblages Associated with Artificial Reefs of Concrete Aggregates or Quarry Stone Offshore Miami Beach, Florida, USA. Aquat. Living Resour. 2002, 15, 95-105. [CrossRef]

130. Carr, M.H.; Hixon, M.A. Artificial Reefs: The Importance of Comparisons with Natural Reefs. Fisheries 1997, 22, 28-33. [CrossRef]

131. Brandt, M.J.; Diederichs, A.; Betke, K.; Nehls, G. Responses of harbour porpoises to pile driving at the Horns Rev II offshore wind farm in the Danish North Sea. Mar. Ecol. Prog. Ser. 2011, 421, 205-216. [CrossRef]

132. Teilmann, J.; Carstensen, J. Negative long term effects on harbour porpoises from a large scale offshore wind farm in the Baltic-Evidence of slow recovery. Environ. Res. Lett. 2012, 7, 045101. [CrossRef]

133. Furness, R.W.; Wade, H.M.; Masden, E.A. Assessing vulnerability of marine bird populations to offshore wind farms. J. Environ. Manag. 2013, 119, 56-66. [CrossRef]

134. Russell, D.J.F.; Brasseur, S.M.J.M.; Thompson, D.; Hastie, G.D.; Janik, V.M.; Aarts, G.; McClintock, B.T.; Matthiopoulos, J.; Moss, S.E.W.; McConnell, B. Marine mammals trace anthropogenic structures at sea. Curr. Biol. 2014, 24, 638-639. [CrossRef]

135. Spagnolo, A.; Fabi, G.; Manoukian, S.; Panfili, M. Benthic community settled on an artificial reef in the Western Adriatic Sea (Italy). Rapp. Comm. Int. Pour l'Exploration Sci. Mer Médititerranée 2004, 37, 552.

136. Verdura, J.; Sales, M.; Ballesteros, E.; Cefalì, M.E.; Cebrian, E. Restoration of a Canopy-Forming Alga Based on Recruitment Enhancement: Methods and Long-Term Success Assessment. Front. Plant Sci. 2018, 9, 1-12. [CrossRef]

137. Fredriksen, S.; Filbee-Dexter, K.; Norderhaug, K.M.; Steen, H.; Bodvin, T.; Coleman, M.A.; Moy, F.; Wernberg, T. Green gravel: A novel restoration tool to combat kelp forest decline. Sci. Rep. 2020, 10, 1-7. [CrossRef]

138. Scheidat, M.; Tougaard, J.; Brasseur, S.; Carstensen, J.; Van Polanen Petel, T.; Teilmann, J.; Reijnders, P. Harbour porpoises (Phocoena phocoena) and wind farms: A case study in the Dutch North Sea. Environ. Res. Lett. 2011, 6, 025102. [CrossRef]

139. Hammill, M.O.; Stenson, G.B. Estimated Prey Consumption by Harp seals (Phoca groenlandica), Hooded seals (Cystophora cristata), Grey seals (Halichoerus grypus) and Harbour seals (Phoca vitulina) in Atlantic Canada. J. Northw. Atl. Fish. Sci. 1999, 26, 1-23. [CrossRef]

140. Chouinard, G.A.; Swain, D.P.; Hammill, M.O.; Poirier, G.A. Covariation between grey seal (Halichoerus grypus) abundance and natural mortality of cod (Gadus morhua) in the southern Gulf of St. Lawrence. Can. J. Fish. Aquat. Sci. 2005, 62, 1991-2000. [CrossRef]

141. Harlin, M.M.; Lindbergh, J.M. Selection of substrata by seaweeds: Optimal surface relief. Mar. Biol. 1977, 40, 33-40. [CrossRef]

142. Beserra Azevedo, F.B.; Carloni, G.G.; Vercosa Carvalheira, L. Colonization of benthic organisms of different artificial substratum in Ilha Grande Bay, Rio de Janeiro. Braz. Arch. Biol. Technol. 2006, 49, 263-275. [CrossRef]

143. Rilov, G.; Benayahu, Y. Vertical artificial structures as an alternative habitat for coral reef fishes in disturbed environments. Mar. Environ. Res. 1998, 45, 431-451. [CrossRef] 
144. De La Fuente, G.; Chiantore, M.; Asnaghi, V.; Kaleb, S.; Falace, A. First ex situ outplanting of the habitat-forming seaweed Cystoseira amentacea var. stricta from a restoration perspective. PeerJ 2019, 7, e7290. [CrossRef]

145. Quaas, Z.; Harasti, D.; Gaston, T.F.; Platell, M.E.; Fulton, C.J. Influence of habitat condition on shallow rocky reef fish community structure around islands and headlands of a temperate marine protected area. Mar. Ecol. Prog. Ser. 2019, 626, 1-13. [CrossRef]

146. Jensen, A.; Wickins, J.; Bannister, C. The Potential Use of Artificial Reefs to Enhance Lobster Habitat. In Artificial Reefs in European Seas; Springer: Dordrecht, The Netherlands, 2000.

147. Spanier, E. What Are the Characteristics of a Good Artificial Reef for Lobsters? Crustaceana 1994, 67, $173-186$. [CrossRef]

148. Cobb, J.S. The Shelter-Related Behavior of the Lobster, Homarus Americanus. Ecology 1971, 52, $108-115$. [CrossRef]

149. Barry, J.; Wickins, J.F. A model for the number and sizes of crevices that can be seen on the exposed surface of submerged rock reefs. Environmetrics 1992, 3, 55-69. [CrossRef]

150. Saunders, D.A.; Hobbs, R.J.; Margules, C.R. Biological Consequences of Ecosystem Fragmentation-A Review. Conserv. Biol. 1991, 5, 18-32. [CrossRef]

151. Ries, L.; Fletcher, R.J.; Battin, J.; Sisk, T.D. Ecological responses to habitat edges: Mechanisms, models, and variability explained. Annu. Rev. Ecol. Evol. Syst. 2004, 35, 491-522. [CrossRef]

152. Jelbart, J.E.; Ross, P.M.; Connolly, R.M. Edge effects and patch size in seagrass landscapes: An experimental test using fish. Mar. Ecol. Prog. Ser. 2006, 319, 93-102. [CrossRef]

153. Selgrath, J.C.; Hovel, K.A.; Wahle, R.A. Effects of habitat edges on American lobster abundance and survival. J. Exp. Mar. Biol. Ecol. 2007, 353, 253-264. [CrossRef]

154. Smith, T.M.; Hindell, J.S.; Jenkins, G.P.; Connolly, R.M. Edge effects on fish associated with seagrass and sand patches. Mar. Ecol. Prog. Ser. 2008, 359, 203-213. [CrossRef]

155. Malcolm, H.A.; Jordan, A.; Smith, S.D.A. Biogeographical and cross-shelf patterns of reef fish assemblages in a transition zone. Mar. Biodivers. 2010, 40, 181-193. [CrossRef]

156. McClanahan, T.R.; Graham, N.A.J.; Calnan, J.M.; MacNeil, M.A. Toward Pristine Biomass: Reef Fish Recovery in Coral Reef Marine Protected Areas in Kenya. Ecol. Appl. 2007, 17, 1055-1067. [CrossRef]

157. Fukami, T.; Nakajima, M. Community assembly: Alternative stable states or alternative transient states? Ecol. Lett. 2011, 14, 973-984. [CrossRef]

158. Kayal, M.; Lenihan, H.S.; Brooks, A.J.; Holbrook, S.J.; Schmitt, R.J.; Kendall, B.E. Predicting coral community recovery using multi-species population dynamics models. Ecol. Lett. 2019, 22, 605-615. [CrossRef]

159. Schoonees, T.; Gijón Mancheño, A.; Scheres, B.; Bouma, T.J.; Silva, R.; Schlurmann, T.; Schüttrumpf, H. Hard Structures for Coastal Protection, Towards Greener Designs. Estuaries Coasts 2019, 42, 1709-1729. [CrossRef]

160. Hammar, L.; Perry, D.; Gullström, M. Offshore Wind Power for Marine Conservation. Open J. Mar. Sci. 2016, 6, 66-78. [CrossRef]

161. Díaz, D.; Mallol, S.; Parma, A.M.; Goñi, R. A 25-year marine reserve as proxy for the unfished condition of an exploited species. Biol. Conserv. 2016, 203, 97-107. [CrossRef]

162. Kough, A.S.; Belak, C.A.; Paris, C.B.; Lundy, A.; Cronin, H.; Gnanalingam, G.; Hagedorn, S.; Skubel, R.; Weiler, A.C.; Stoner, A.W. Ecological spillover from a marine protected area replenishes an over-exploited population across an island chain. Conserv. Sci. Pract. 2019, 1, e17. [CrossRef]

163. Burkhard, B.; Gee, K. Establishing the resilience of a coastal-marine social-ecological system to the installation of offshore wind farms. Ecol. Soc. 2012, 17, 42. [CrossRef]

164. Hewitt, J.E.; Thrush, S.F. Monitoring for tipping points in the marine environment. J. Environ. Manag. 2019, 234, 131-137. [CrossRef]

165. Mavraki, N.; Degraer, S.; Moens, T.; Vanaverbeke, J. Functional differences in trophic structure of offshore wind farm communities: A stable isotope study. Mar. Environ. Res. 2020, 157, 104868. [CrossRef]

166. Claisse, J.T.; Pondella, D.J.; Love, M.; Zahn, L.A.; Williams, C.M.; Williams, J.P.; Bull, A.S. Oil platforms off California are among the most productive marine fish habitats globally. Proc. Natl. Acad. Sci. USA 2014, 111, 15462-15467. [CrossRef]

167. Ajemian, M.J.; Wetz, J.J.; Shipley-Lozano, B.; Dale Shively, J.; Stunz, G.W. An analysis of artificial reef fish community structure along the northwestern Gulf of Mexico shelf: Potential impacts of "rigs-to-reefs" Programs. PLoS ONE 2015, 10, 1-22. [CrossRef] 
168. Todd, V.L.G.; Lavallin, E.W.; Macreadie, P.I. Quantitative analysis of fish and invertebrate assemblage dynamics in association with a North Sea oil and gas installation complex. Mar. Environ. Res. 2018, 142, 69-79. [CrossRef]

169. McLean, D.L.; Taylor, M.D.; Giraldo, A.; Partridge, J.C. An assessment of fish and marine growth associated with an oil and gas platform jacket using an augmented remotely operated vehicle. Cont. Shelf Res. 2019, 179, 66-84. [CrossRef]

170. Inger, R.; Attrill, M.J.; Bearhop, S.; Broderick, A.C.; James Grecian, W.; Hodgson, D.J.; Mills, C.; Sheehan, E.; Votier, S.C.; Witt, M.J.; et al. Marine renewable energy: Potential benefits to biodiversity? An urgent call for research. J. Appl. Ecol. 2009, 46, 1145-1153. [CrossRef]

171. Dons, S.; Jensen, D.J.; Struve, A.; Nielsen, B. Vindeby Havmøllepark; DONG Energy. 2016, pp. 1-61. Available online: https://ens.dk/sites/ens.dk/files/Vindenergi/miljoevurdering_for_nedtagning_af_vindeby_ havmoellpark_inkl_bilag.pdf (accessed on 8 May 2020).

172. Bull, A.S.; Love, M.S. Worldwide oil and gas platform decommissioning: A review of practices and reefing options. Ocean Coast. Manag. 2019, 168, 274-306. [CrossRef]

173. Fowler, A.M.; Jørgensen, A.M.; Svendsen, J.C.; Macreadie, P.I.; Jones, D.O.B.; Boon, A.R.; Booth, D.J.; Brabant, R.; Callahan, E.; Claisse, J.T.; et al. Environmental benefits of leaving offshore infrastructure in the ocean. Front. Ecol. Environ. 2018, 16, 571-578. [CrossRef]

174. Smyth, K.; Christie, N.; Burdon, D.; Atkins, J.P.; Barnes, R.; Elliott, M. Renewables-to-reefs?-Decommissioning options for the offshore wind power industry. Mar. Pollut. Bull. 2015, 90, 247-258. [CrossRef]

175. Topham, E.; McMillan, D. Sustainable decommissioning of an offshore wind farm. Renew. Energy 2016, 102, 470-480. [CrossRef]

(C) 2020 by the authors. Licensee MDPI, Basel, Switzerland. This article is an open access article distributed under the terms and conditions of the Creative Commons Attribution (CC BY) license (http://creativecommons.org/licenses/by/4.0/). 